Article

\title{
Geoheritage of the Monchegorsk Igneous Layered Paleoproterozoic Intrusion (Kola Peninsula, Arctic Russia): Evaluation and Geotourism Opportunities
}

\author{
Miłosz Huber ${ }^{1, *}$, Galina Zhigunova ${ }^{2}$, Maria Menshakova ${ }^{3}$, Olga Iakovleva $^{4}$ and Maria Karimova ${ }^{5}$ \\ 1 Department of Geology, Soil Science and Geoinformacy, Faculty of Earth Science and Spatial Management, \\ Maria Curie—Skłodowska University, 2d /107 Kraśnickie Rd., 20-718 Lublin, Poland \\ 2 Department of Philosophy and Social Sciences, Murmansk Arctic State University, Captain Egorov, 15, \\ 183038 Murmansk, Russia; galina-zhigunova@yandex.ru \\ 3 Laboratory Monitoring and Preservation of Natural Ecosystems of the Arctic, Murmansk Arctic State \\ University, Captain Egorov, 15, 183038 Murmansk, Russia; dendrobium@yandex.ru \\ 4 Department of Applied Linguistics, Faculty of Philology, Maria Curie Skłodowska-University, \\ 5 Maria Curie—Skłodowska Sq, 20-031 Lublin, Poland; olga.iakovleva@mail.umcs.pl \\ 5 Lapland Nature Reserve, Zelenyi Lane, 8, 184506 Monchegorsk, Russia; karimova@laplandzap.ru \\ * Correspondence: milosz.huber@mail.umcs.pl; Tel.: +48-692283572
}

Citation: Huber, M.; Zhigunova, G.; Menshakova, M.; Iakovleva, O.; Karimova, M. Geoheritage of the Monchegorsk Igneous Layered Paleoproterozoic Intrusion (Kola Peninsula, Arctic Russia): Evaluation and Geotourism Opportunities. Heritage 2021, 4, 3583-3610. https:/ / doi.org/10.3390/heritage4040198

Academic Editor: Dmitry A. Ruban

Received: 5 August 2021

Accepted: 11 October 2021

Published: 18 October 2021

Publisher's Note: MDPI stays neutral with regard to jurisdictional claims in published maps and institutional affiliations.

Copyright: (c) 2021 by the authors. Licensee MDPI, Basel, Switzerland. This article is an open access article distributed under the terms and conditions of the Creative Commons Attribution (CC BY) license (https:/ / creativecommons.org/licenses/by/ $4.0 /)$.

\begin{abstract}
Monchegorsk is an intrusion complex of basic and ultrabasic rocks of the Paleoproterozoic age. This complex formed during active magmatic mobility that took place in NE Scandinavia $2.5 \mathrm{Ga}$ years ago. These were the subject of intensive exploration and exploitation at the beginning of the 20th century, the latter carrying on through to the beginning of the 21st century. This contributed to the creation of some different forms of post-industrail mining infrastructure in the area. Many mining settlements, including Monchegorsk, mining plants, adits and quarries were established during this time, the relics of which are still present today. The Monchegorsk intrusions complex is formed by several fragmented massifs: Traviannaya, Kumuzhia, Nittis, Sopcha, Nyud, Poaz, and Monchetundra, the highest elevations of which reach up to $1000 \mathrm{~m}$ above sea level. These massifs form a landscape of "islands" and mountain ranges that have influence upon the regional landscape over several tens of kilometers. Their geography is characterized by numerous reliefs, glacial cirques, rocky thresholds with waterfalls and trough lakes. The potential of this region lies in the heritage of historical exploitation, numerous monuments of which have been preserved to this day. An important value is a landscape resulting from the relief of these mountains, highlighted by glacial activity in the Pleistocene. There are also interesting examples of Arctic fauna and flora, and of the rocks that form the bedrock in this intrusion. Some of the mineralization of these outcroppings can also be admired in the collections of the local museum that serves as a geocenter. The possibility of admiring relatively easily accessible views (the international route St. Petersburg-Murmansk-Kirkenes passes through the middle of the hills) and the interesting geology of the area abounding in rocks of mineralogical significance, their exposures, and history, along with the possibility of observing various post-industrail forms, make this area of great tourist potential. This article describes the most interesting exposures of outstanding tourist value and proposes routes connecting these points. It also discusses the problem of securing these exposures and the necessary tourist infrastructure, which is currently lacking.
\end{abstract}

Keywords: geoheritage; historical mining objects; Monchegorsk; Murmansk District; Arctic Russia; touristic values

\section{Introduction}

The Monchegorsk intrusions area is located northeast of the Scandinavian Peninsula above the Arctic Circle. It is the central part of Murmansk District in the border area between Lapland and the Kola Peninsula. The Monchetundra Mountains form massive, 
stretched hills with the length reaching $250 \mathrm{~km}$ and the width from 50 to $20 \mathrm{~km} \mathrm{[1-3].} \mathrm{An}$ important second element is the area called the Monchepluton, which is built of several "island" massifs between which there are deep valleys and flattened terrain along with lakes and Pleistocene sediments. It is dominated by the isolated massifs of Traviannaya, Kumuzhia, Nittis, Sopcha, Nyud, Poaz, and Vurechuaivench (Figures 1 and 2).

The Monchetundra is typified by massifs with long approaches, prominent rockfalls, waterfalls, and steep slopes. The Monchetundra massif is higher than the Monchepluton area and dominates the landscape. The highest peak reaches an altitude of about $965 \mathrm{~m}$ a.s.l. [3]. The slopes of these massifs tend to be varied, dominated by glaciers covering the summit areas and small glacial cirques. The peaks of the mountains offer a picturesque view of the city of Monchegorsk, and Lake Imandra, the Khibiny Mountains, and Lapland in general (Figure 1).

This landscape is superimposed by numerous forms related to the weathering of rocks and anthropogenic activities (Figure 2 and Figure 3). Due to the area being occupied, the discussed massifs are an important landscape, cultural, and ethnographic element. Imandra Lake, the biggest trough lake in the region, $120 \mathrm{~km}$ long, runs on the eastern side of the massif. It is the geographical border separating Lapland in the west from the Kola Peninsula in the east [4]. This lake is also the natural boundary of the Saami tribes, who are mainly located east of this lake [5,6]. The slopes of the Monchetundra and Vurechuaivench massifs show a succession of vegetation types, ranging from a forest layer at the base of the mountains through forest-tundra and tundra to arctic desert in the summit areas. There are ski trails in the Nittis and Nyud mountains. This makes it an attractive tourist destination thanks to the availability of eye-catching monuments and the Polar Days in summer and the Polar Nights in winter, especially since the international road St. PetersburgMurmansk-Kirkenes (Norway) or-Rovaniemi (Finland) runs through the middle of the Monchepluton massif. Snow in this area sometimes lies until the beginning of May. In Monchegorsk there is a railroad line (freight nature) and a mineralogical museum. Both the surroundings characteristic of the alpine landscape and environment and the valuable mineral specimens have made this area worthy of protection and the subject of study of many researchers. The works of geologists Wojtekhovsky [7] and Johanson [8] have contributed to many interesting initiatives, although their studies were created primarily for narrowly focused specialists, such as mineralogists and geologists, mainly emphasizing the geological significance of the area. However, due to its geo-touristic and natural values, the area deserves more protection and description in a broader natural and cultural context. This approach to geo-conservation has been known since the 1990s. In 2018, Reynard and Brihla [9] provided an extensive description of these trends. Attention to the need to protect inanimate nature sites has become a reality since Geoparks began to be established, some of which have been listed as UNESCO World Heritage Sites [10]. The need to protect these sites was already written about by Alexandrowicz and Kozłowski in 1999 [11]. Furthermore, the context of paying attention to geo-sites was described by Brihla in 2018 [12]. There are many works defining geoheritage and geodiversity [13-17]. The issue of conservation and geo-conservation is an important step to secure and pass on to future generations the land in question. This has been written about by Gray in 2005 [18], Brocks and Semeniuk in 2007 [19], Henriques et al. [20], Burek [21], Bratton et al. [22], in numerous works by Tomić with different co-authors [23,24], and Crofts and Gordon [25]. The authors of this paper first mentioned the need for conservation in the region in 2017 [26] and then in a 2020 paper [27]. This approach is in line with the global trends of preservation of inanimate objects, examples of which can be found around the world: Stone Hammer Geopark in Canada [28], Magma Geopark in Norway [29], Huangshan Geopark in China [30]. The aforementioned serve to typify the value of sustainable development, allowing for the diversification of regional income through increased tourism.

Conservation and protection activities of the Monchetundra area were institutionalized in 1965 with the delimitation of the territorial boundaries of Lapland Nature Reserve [4]. However, after that, no real action was taken. The established protected area 
lacks hiking trails, signage, shelters, and other forms of tourism infrastructure, which are essential conservation measures needed to expose the landscape to tourists. The practice of creating nature reserves in the Russian Federation has a long tradition: numerous protected areas were created in the Altai [31] and the Caucasus [32] regions in the early 20th century.

Apart from the Lapland Reserve, the Kola Peninsula has two more large protection zones: the Kandalaksha Nature Reserve and the Pasvik Nature Reserve [2]. However, despite the experience of creating adequate tourist infrastructure in the Altai and the Caucasus, significant initiatives in the Kola region are still insufficient. Recently, an educational ecological path has been launched in the area (in the Chunoziero area of the Laponia nature reserve), but in general, Monchetundra and Monchepluton lack such infrastructure elements [2]. Moreover, there are many earthen roads used by off-road cars and motorcycles and numerous traces of activities carried out by amateur recreationists and mineral collectors, which contribute to the devastation and littering of the area and further land degradation in the harsh polar climate. This is particularly acute in the vicinity of the town of Monchegorsk and the expressway due to the particularly easy access to these sites. The sites in question are within the range of potential tourist attractions and can be visited during a 1-3 day trip depending on the traveler's pace, physique, and the current weather conditions. These massifs are located near the mining town of Monchegorsk, which can be reached by bus from Murmansk (about $110 \mathrm{~km}$ [2]). Another option is to go by car along the expressway towards Monchetundra (see Tables 1 and 3), walk towards Sopcha towards Poaz (about $25 \mathrm{~km}$ ) or Hippik, and continue towards Vaikis waterfall (about $37 \mathrm{~km}$ ). This allows one to make the trip without much logistical effort, with few supplies, and without having to plan a multi-day trek. A significant problem remains that even after the area was granted protected status, there is still little accessible tourist infrastructure.

This article aims to show the uniqueness of the studied area of Monchegorsk and the area protected by Lapland National Park and to show the possibility of developing hiking trails [33]. The idea proposed by the authors is to highlight the area in question by establishing hiking trails and to bring to light specific zones related to geology, nature, culture and research history. In the work, we evaluated individual geo-sites based on the methods presented below (see Section 3).

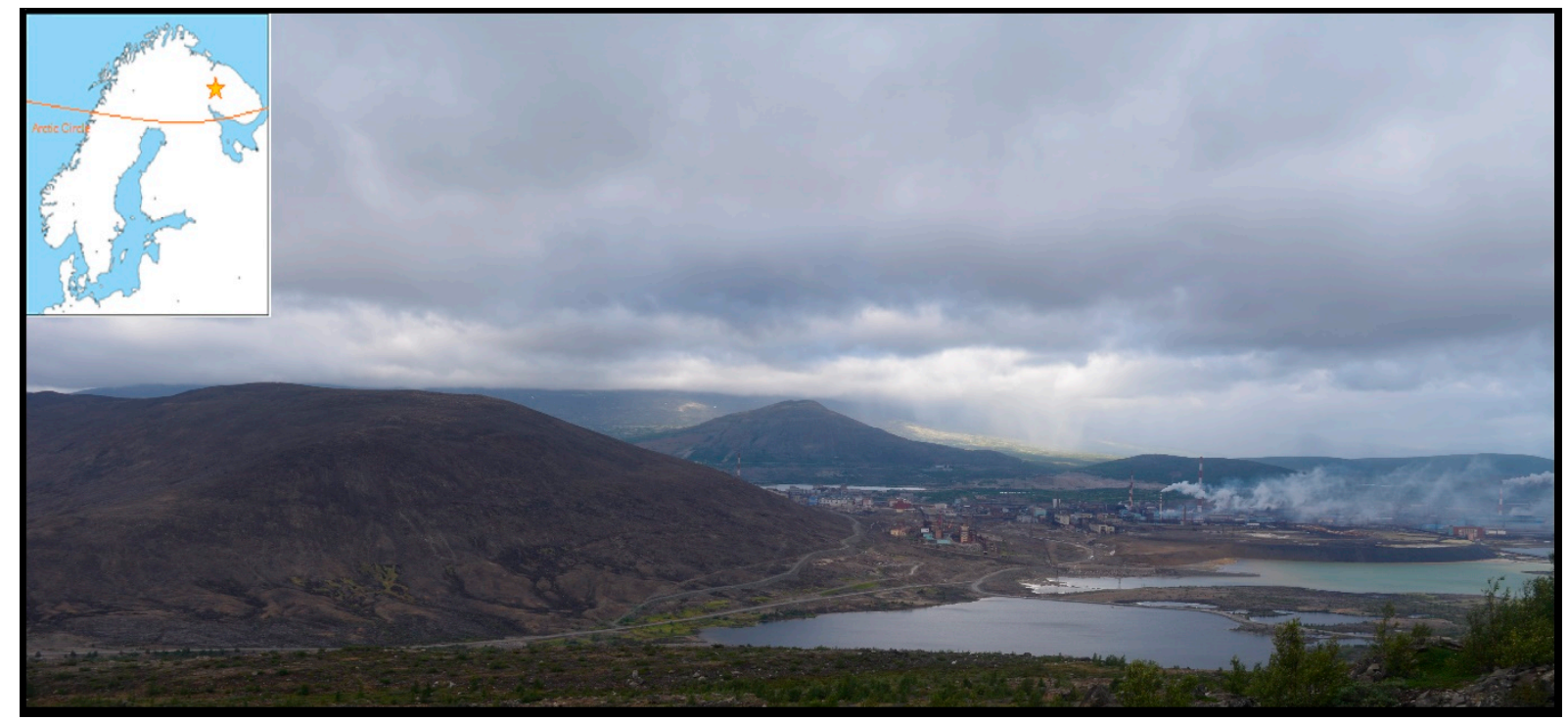

Figure 1. Typical landscape and localization of the Monchegorsk area. 


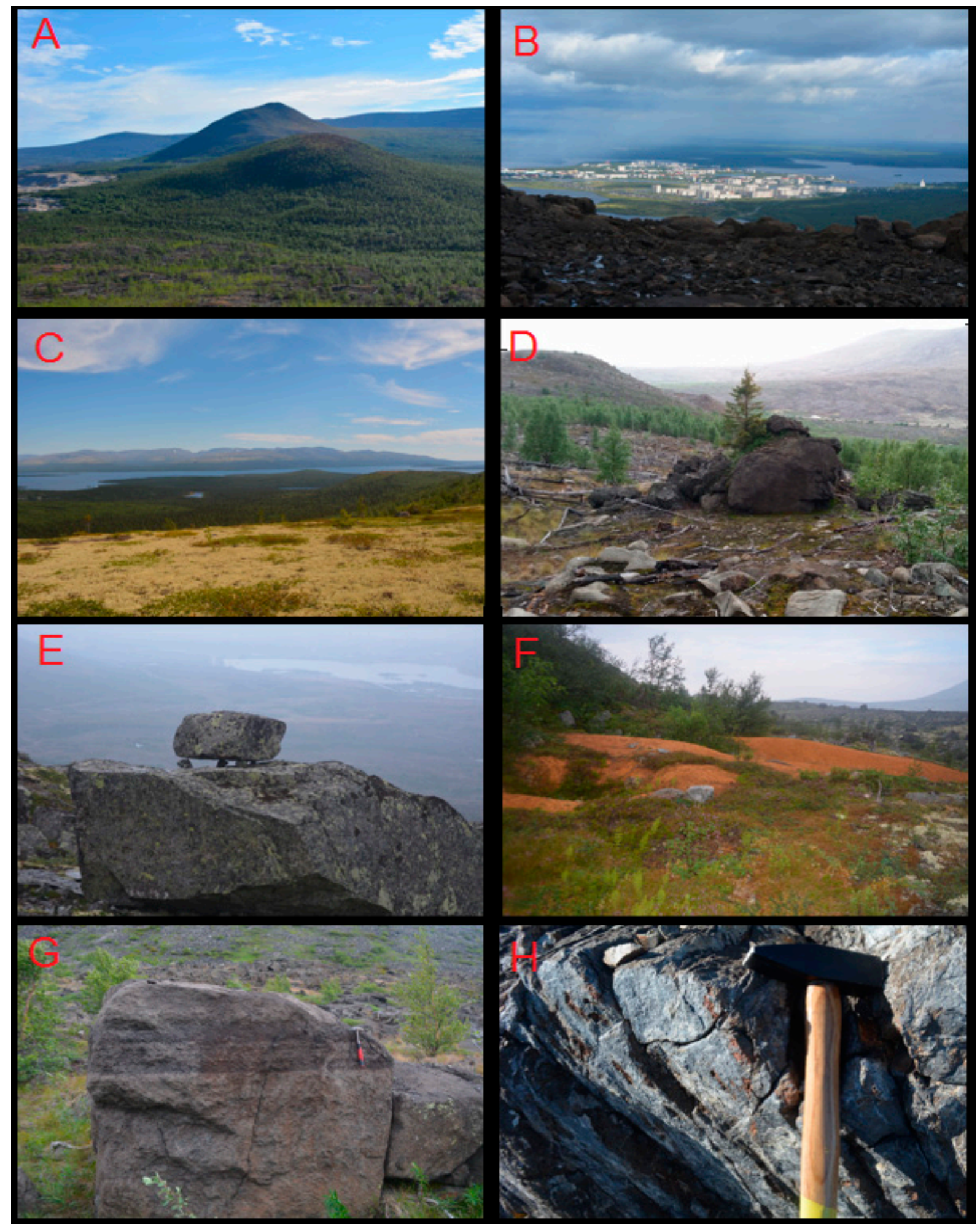

Figure 2. Typical landscape from the Monchegorsk Mountains: View of Kumuzhia, Nittis and in the distance (right), Monchetundra Massif with Hippik Mountain (A), View of Monchegorsk City and Lake Imandra (B), Lake Imandra and Khibina in the distance $(\mathbf{C})$, olivine gabbronorites forming picturesque rocks in the Nyud slopes (D), "seids" very impressive glacial erratics standing on small pebbles-Monchetundra (E), weathering caps over chromite deposits in Dunite block (F), the rhythmicity of intrusions visible in layers of orthopyroxenites in Nyud norites (G) xenoliths of harzburgites in orthopyroxenites in Traviannaya $(\mathbf{H})$. 


\section{Geographical and Geological Settings}

\subsection{Geomorphological Characteristics}

Upon analyzing the present character of these hills, one can see in them a strong influence of post-glacial erosion in the form of manifested blocks (as in the case of Vurechuayvench) or sharpening of slopes and numerous rock outcrops as in the case of Nittis, Sopcha and Nyud (Figure 2B). In the valleys between these massifs, especially between the meridional and latitudinal wings, thicker glacial sediments are found and have been exploited as different fractions of aggregate [34]. The ice sheet during the Neogene glaciations was responsible for these processes. On the other hand, the orography of these massifs is unlikely to have allowed ice sheets to persist in their summit zones except at Sopcha, Nyud, and Vurechuayvench, which have a rounded summit character, indicating the past presence of a small glacier in the summit parts, forming the proto-cyclonic character of these zones. Glacial erratics found in the summit zones demonstrate that they were covered by ice during the Pleistocene glaciation [34]. After the glacier receded, the Arctic climate made its mark by exacerbating the positive forms of the summit spurs and local valleys by creating sharp ravines in them. This also made the geology of the area clearer, making the tectonic zones more visible. The rock blocks in the summit parts form rounded forms (spherical weathering) resulting from the exfoliation of rocks due to frost and insolation. Their dark colors resulting from the prevalence of pyroxenes cause the heating of these rocks in summer (Figure 2D), which has resulted in a zone of mineral deposition in the form of rock clasts.

The weathering surface of these outcrops highlights their structure and petrological changes, which increases the clarity of the rhythmic layering processes or the occurrence of porphyritic zones, any xenoliths, etc. This greatly facilitated fieldwork and specimen collection.

\subsection{Characteristics of the Geological Structure of the Massif}

The Monchepluton intrusion is an interesting occurrence of mafic and ultramafic rocks. It surrounds Monchegorsk city, from the west, south and east, and is an important part of the city's landscape. It is built of two wings with a roughly meridional (N-S) and latitudinal (W-E) course (Figure 3). In the meridian wing there are massifs from the north: Traviannaya, Kumuzhia, Nittis (called NKT). In the latitudinal wing from the west: Sopcha, Nyud, Poaz and lying south of them: Vurechuayvench [35-38]. The intrusion is surrounded from the north by archaic rocks of the Kola series and from the east and south by the Proterozoic formations of the Imandra-Varzuga belt. The discussed intrusion is built up with pyroxenites and labradorites and accompanied by rocks containing chromites and iron-nickel and copper sulfide ores. Recent studies have also shown the presence of PGE mineralization in them [37,39].

This massif is an early Proterozoic intrusion, which was expended at the age of $2.5 \mathrm{Ga}$ [40-42] in a large plume cycle after the breakup of the Kenorland supercontinent [43-49]. In its various blocks forming separate ranges, one can see many interesting features relating to the geological structure of the massif, such as the passage of one rock in the second injection zone autobreccia and xenoliths. In the blocks belonging to the NKT, there are rocks of dunite and harzburgite, and clinopyroxenite rocks containing chromites (Figure 4A) and olivine-pyroxene bodies (Figure 4B). In the area of Sopcha, Nyud, and Poaz, there are orthopyroxenites, olivine norites and gabbronorites-also with numerous interesting zones showing the rhythm of the formation of intrusion [37,50-53]. In the Hippik area, the gabbro is exposed [37,38]. The whole intrusion is cut by numerous mineral veins of dolerites and prehnite-carbonate rocks and is also cemented with sulfides, sometimes taking massive forms, while in tectonic zones, there are breccias and mylonites [54-56]. These rocks are described below:

- Dunites are rocks, the background of which is filled with olivine crystals, usually strongly cracked and serpentinized (Figure 4A,C). Next to these crystals, small chromite grains and iron oxides can be identified. In the rock, talc, antigorite and fine grains of 
sulfides are found. This rock also contains single crystals of orthopyroxene, and sometimes also plagioclases. However, where these minerals are visible, they are separated from the rest of the rock by reactive crowns formed on the olivine-plagioclase border, composed mainly of phlogopite.

- Chromitites are massive rocks made of chromite, which frequently alternate with dunites of various thicknesses, sometimes up to $1 \mathrm{~m}$ (Figure $4 \mathrm{~A}$ ). They are usually composed of chromite, which easily winds up on the surface, transforming into hematite pseudomorphoses. In addition to chromite, there are small crystals of olivine, usually cracked and serpentinized. In the rock, there are also single crystals of orthopyroxene filling the spaces of the chromites crystallized on their background.

- Harzburgites are olivine-orthopyroxene rocks. Olyvines in these rocks form large crystals, sometimes with a visible sector texture, against the background of orthopyroxenes (bronzite, Figure 4D). In these rocks, accessory chromite is sometimes visible, usually with a zonal texture (the inner part is enriched with chrome, and the outer part-iron). In the zones of sulfide mineralization, the serpentinization of these rocks is usually evident, sometimes even with the appearance of small amounts of plagioclase. There are reaction crowns, phlogopite, tremolite, and vermiculite, while talc carbonates are visible.

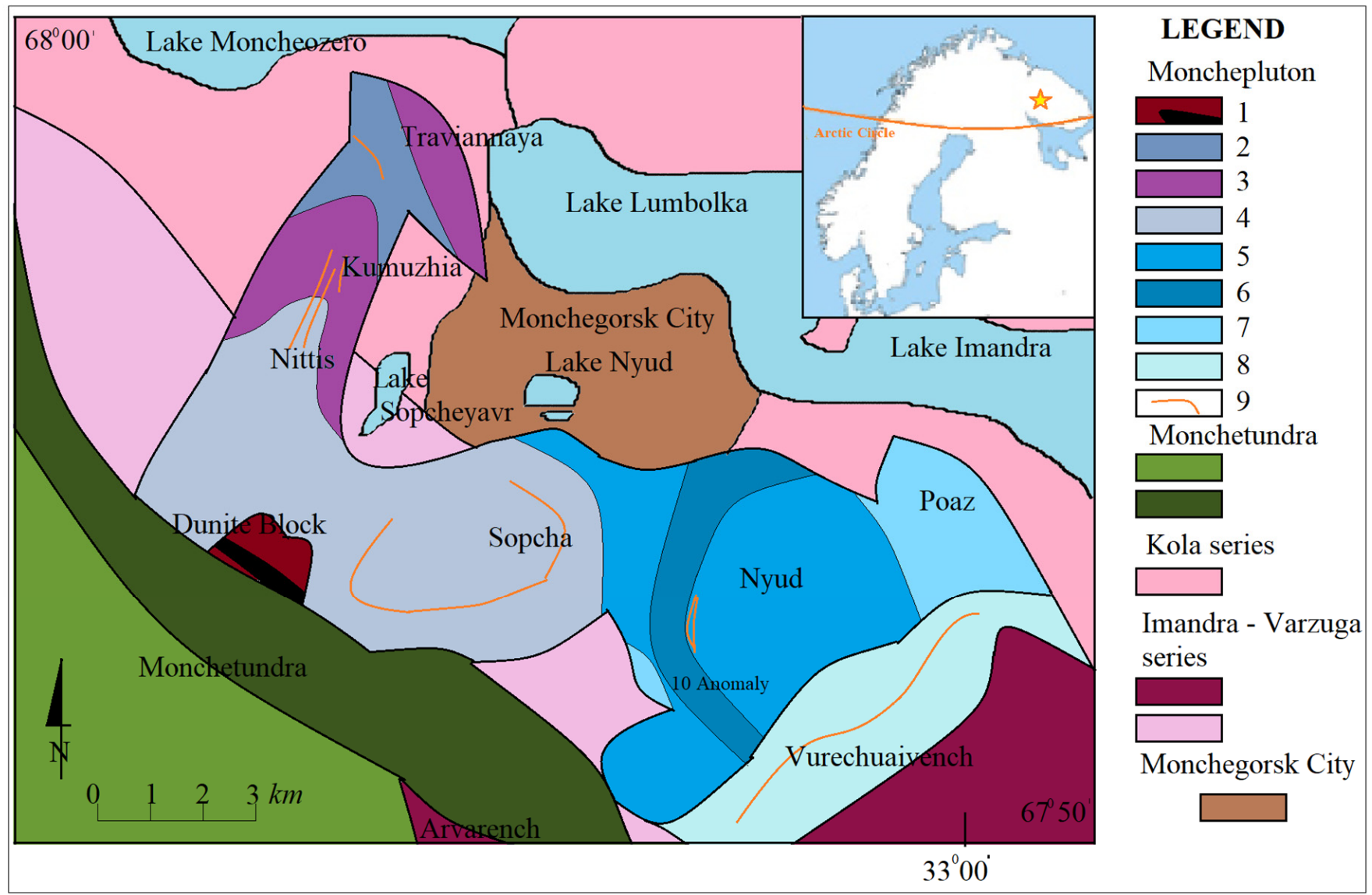

Figure 3. Geological sketch of the Monchegorsk intrusions with the marked case-study area (after [36,38], changed by authors): Monchepluton: 1. Dunites and chromitites; 2. Harzburgites; 3. Other peridotites; 4. Orthopyroxenites; 5. Olivine norites; 6. Gabbro-norites; 7. Gabbro; 8. Gabbro-anorthosites; 9. Massive sulfide mineralization, Monchetundra; 10. Gabbro-anorthosites; 11. Peridotites, Kola series; 12. Archean gneisses, Imandra Varzuga series; 13. Hypersthene diorites; 14. Metasediments and metavolcanic rocks. 


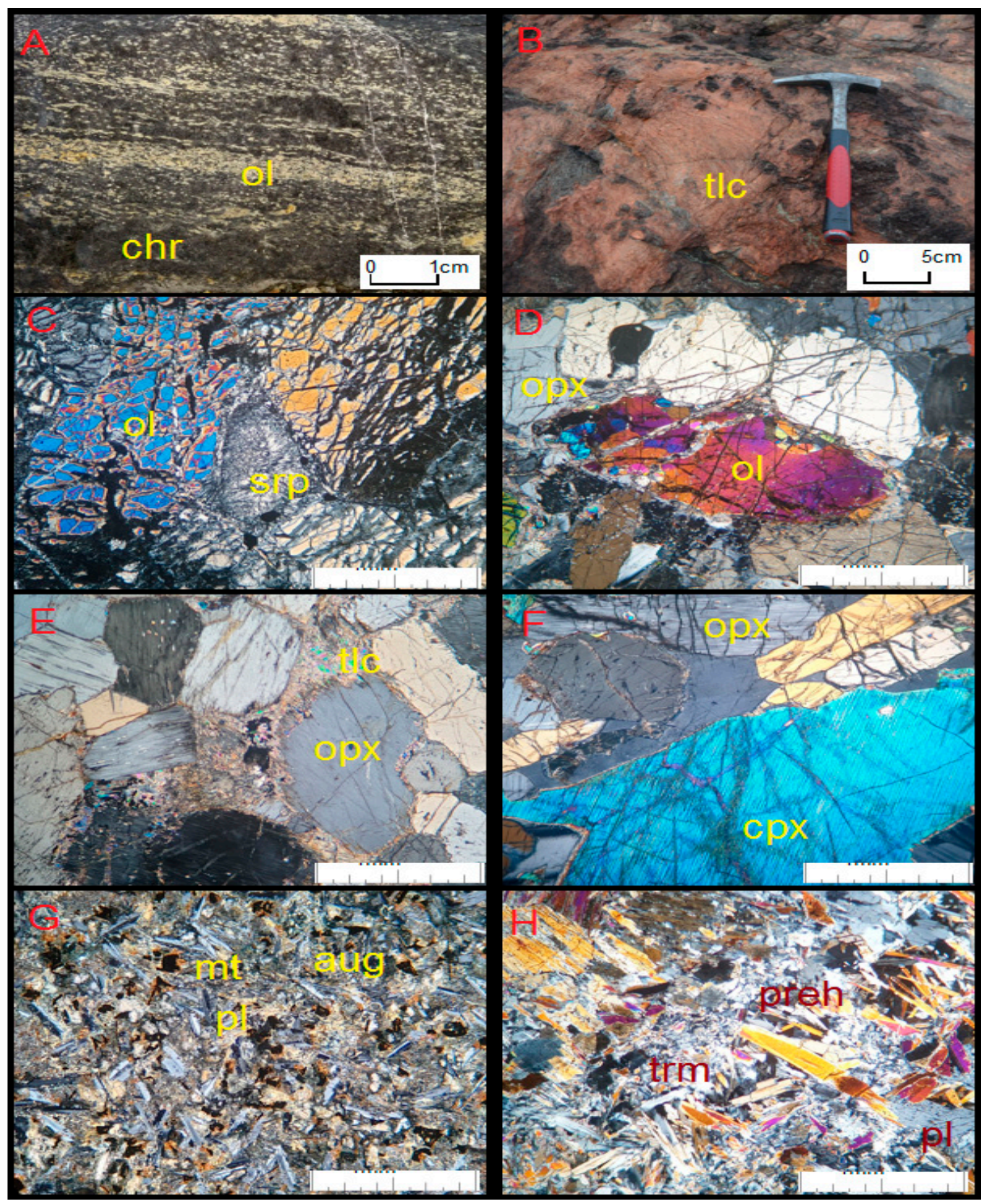

Figure 4. Macro photographs $(\mathbf{A}, \mathbf{B})$ and microphotographs $(\mathbf{C}-\mathbf{H})$ of the typical rock samples: interbedding of dunite with chromitite in dunite block (A), tectonic mirror highlighted by talc, serpentine, and hematite minerals in harzburgite (B), serpentinized olivine in dunite (C), olivine and orthopyroxenes in harzburgite (D), talc visible between orthopyroxenes in orthopyroxenite $(\mathbf{E})$, ortho- and clinopyroxenes in norite $(\mathbf{F})$, an example of an ophitic texture in diabase-mineral veins (G), prehnite, tremolite and albite in the vicinity of prehnite-carbonate veins $(\mathbf{H})$. Abbreviations: ol—olivine, tlc-talc, srp—serpentine, opx—orthopyroxene, cpx—clinopyroxene, aug—augite, $\mathrm{mt}$-magnetite, pl—plagioclase, trm—tremolite, preh-prehnite.

Orthopyroxenites are massive, monotonous rocks made of orthopyroxene. They have an even-grained texture and weather and break down into individual grains (Figure 4E). 
They contain orthopyroxene (mainly bronzite), sometimes with small admixtures of clinopyroxene, talc and plagioclase.

- Norites and olivine norites are rocks with visible orthopyroxene crystals, between which there are plagioclases, sometimes forming an ophitic texture (Figure 4F). Against the background of these minerals, large olivine crystals are sometimes visible, much larger than orthopyroxenes and serpentinized to a different extent. Among these crystals, there is accessory chromite, magnetite, talc, antigorite, and, occasionally, sulfides.

- Gabbronorites are rocks, which, apart from orthopyroxene, contain clinopyroxene that usually forms large crystals with occasional orthopyroxene fouling. Between these crystals are plagioclases (sometimes also corroded), jagged chromite and sulfides.

- Gabbro is a rock that is mainly made of clinopyroxene, which gives them a greenish color. Sometimes the clinopyroxene in these rocks becomes quite large, creating a porphyry texture (especially in the Hippik region in the Monchetundra massif). In addition to these minerals, there are usually clinozoisite, epidote, tremolite, and also plagioclase-which occasionally also come in large sizes and are usually sericitized to different degrees.

- Metaanortosites are rocks heavily altered by younger intrusions in the neighborhood. They are made of hornblende, next to which there is relict clinopyroxene interwoven with tremolite. Besides these minerals, there are plagioclases, and in their vicinity there is titanite, usually with relict ilmenite inside.

- Dolerites are formed by various types of veins with a thickness of up to $1 \mathrm{~m}$, usually, they have an ophitic texture emphasized by plagioclases, between which there is augite, sometimes also tremolite and biotite, and numerous minerals of ilmenite and magnetite (Figure 4G).

- Prehnite-carbonate mineral veins are bright rocks that are up to a few $\mathrm{cms}$ thick and are usually emphasized by the amphibole enrichment of the surrounding rocks in the contact zone. They are made of prehnite, sometimes creating nice palisade-shaped crystals, between which there is hematite, albite, and carbonate (Figure $4 \mathrm{H}$ ).

- Breccias and mylonites are formed in fault zones and are usually made of crushed rocks in their vicinity. In Monchepluton, one can find breccias and mylonites in which crushed crystals of olivine and orthopyroxene can be seen, often along with tremolite and talc, with sulfides usually acting as cement.

- Massive sulfides. Sulfides in the massif in question form a dispersed (described above) nest form, creating an accumulation of minerals among silicate rocks and a massive form in the form of veins, sometimes co-occurring with magnetite. They are made up of large, twin pentlandite crystals, next to which there is pyrrhotite, and sometimes troilite. Chalcopyrite is also found in contact or micro tectonic zones. Bornite, digenite, and galena, sphalerite, zincite and pyrite are secondary in these minerals. Bornite and digenite are usually formed at the border of chalcopyrite and magnetite. In the vicinity of these minerals, they are enriched with tellurides and bismuths of platinum and palladium $[37,39]$.

The surrounding Monchepluton intrusion is composed mainly of large-crystalline varieties of gabbro-anorthosites and other rocks of the gabbro group with admixtures of peridotites, which are located both in the form of overflows in the discussed rocks and small intrusions [35-38]. In the area of these intrusions there are rare and valuable rock specimens (e.g., orthopyroxenite, olivine breccia, layered dunites/chromitites, massive sulfide veins, gabbro, and peridotite pegmatites) and minerals (e.g., kotulskite, maslovite, mitrofanovite, sperrylite) [37]. These massifs play a significant role in the formation history of NE Scandinavia, as they formed during the 2.5 Ga period during hot spot activity [43-48]. They are located in a breakup zone called the Kola-Lapland Mobile Belt, which was still active for a further $2 \mathrm{Ga}[37,57]$.

The massif is separated by deep gentle valleys (Figure 2A) heavily buried by glacial and fluvioglacial sediments. In the exposed hills, a different degree of weathering is visible, also resulting from the influence of the Pleistocene glaciation, which contributed 
to the creation of large valleys covered with coarse glacial and fluvioglacial sediments. Observations of the slopes of these massifs also indicate the occurrence of boulder fields and small glaciers in them, which may have been small glaciers.

\subsection{Historical Heritage}

Apart from the exploitation heritage, there are also traces of the activities of the Saami, who lived in this area for about 2000 years $[5,6]$. In the area of Chuna Lake, the old trap pits where animals were caught alive and tamed have been preserved. The "seids" discussed above were worshipped by these indigenous people as so-called "power stones". There is an alternative hypothesis that at least some rock formations are megalithic handiwork because especially in this area the blocks making up these are made of the same rocks as their surroundings, not like erratics made of different magma and metamorphic rocks. These objects are relatively common in the Monchetundra area. The area in question was discovered only in the 20th century when expeditions of geologists analyzing the interior of the Murmansk region progressed with the construction of the railroad, which was completed in 1918 [6]. The first major geological studies of the region were published in the 1930s by A.E. Fersman, D.F. Murashov and V.K. Kotulsky [38]. Intensive exploitation of sulfide ores was initiated in the mid-20th century period. At that time mines, shafts and adits were built by way of the participation of forced laborers. This work was continued in the sixties and seventies with the use of drilling and geophysical methods. At the end of the 20th century, a chrome deposit was documented, and at the beginning of the 21st century PGE mineralization was, too. However, for economic reasons the exploitation of the area was discontinued, the mining infrastructure being abandoned in the 1990s. In the 21st century, only a metallurgical plant operates, melting ore brought in from other deposits.

\subsection{Climatic and Ecological Characteristics}

The Monchepluton area is located in the Arctic zone in the central part of the Murmansk District. The location of the town in the central part of the peninsula makes the climate a bit sharper compared to Murmansk, though it is certainly milder than Apatite. Monchegorsk is sheltered by the hills from the south winds and the presence of Imandra's large lake brings about a significant reduction in climate extreme in the city. The January temperatures are around $-12{ }^{\circ} \mathrm{C}$, while July temperatures are around $+14{ }^{\circ} \mathrm{C}$ (the extrapolation of Apatity and Murmansk data) $[2,4,58,59]$. The impact of industry, mountains and lake increases rainfall and transpiration on warmer days. Among the massifs of NKT, the highest is Nittis (618 $\mathrm{m}$ above sea level, towering over Monchegorsk, located at an altitude of about $150 \mathrm{~m}$ above sea level), where there is an inactive chairlift and ski trails. In the top parts of this mountain, the receding of the tundra and the transition to moss-growth overstory are marked. The other peaks of Kumuzhia (339 m) and Traviannaya ( $376 \mathrm{~m})$ are much lower and may have been originally covered with dwarf forest. Sopcha $(507 \mathrm{~m})$ is also a high massif, as is Nyud $(465 \mathrm{~m})$, which also has an active ski lift. A similar peak is Vurechuayvench $(470 \mathrm{~m})$, which has developed boulder fields near the top, where the tundra changes to moss-growth layers above. The lower one is Poaz with a TV transmitter on the top. This peak is completely covered with forest ( $379 \mathrm{~m})$. In this area, one can see the vegetation storied, which is disturbed by intensive human activity, consisting of a massive forest clearing in the first half of the 20th century, followed by the location of heavy industry. It is currently undergoing secondary succession. This is particularly visible in the areas of Nyud, Nittis, and Sopcha. The vegetation in the area in question is forest, which is located at the foot of the mountains. In this forest, there is Scots pine (Pinus silvestris), Lapland birch (Betula lapponica), and numerous species of vascular plants in the undergrowth that are characteristic of the area in question, such as European creeper (Trollius europaeus), Lapland poppy (Papver lapponica), woolly pine (Eriophorum angustifolium) in swampy zones and numerous berries (Vaccinum sp.) [60-63]. The Chuna Lake area has moist old spruce and pine forests, some trees are as old as 300 years (Lapland Nature Reserve information). Higher up, the forest changes into forest-tundra with dwarf trees, including Lapland birch 
and willows (Salix reticulata) and gives way in the highest parts to moss-lichen tundra. Lichens of the genus Cladonia are particularly well visible here. These are accompanied by plants from the genus Saxifragaceae, hare's sorrel (Oxalis acetosella), numerous fungi, mosses, and forbs. Hares (Lepus europaeus) can be seen on the slopes of these mountains, while moose (Alces alces) and brown bears (Ursus arctos) are common in the valleys.

\section{Materials and Methods}

In the Monchegorsk area, the authors conducted detailed research from 2008 to 2020. During the fieldwork, the focus was oriented on the inventory of values, photographic documentation, and rock sampling. This work was also conducted in conjunction with ecologists from Lapland Nature Reserve. The purpose of these analyses was to demonstrate the potential of the site in question (Figure 5).

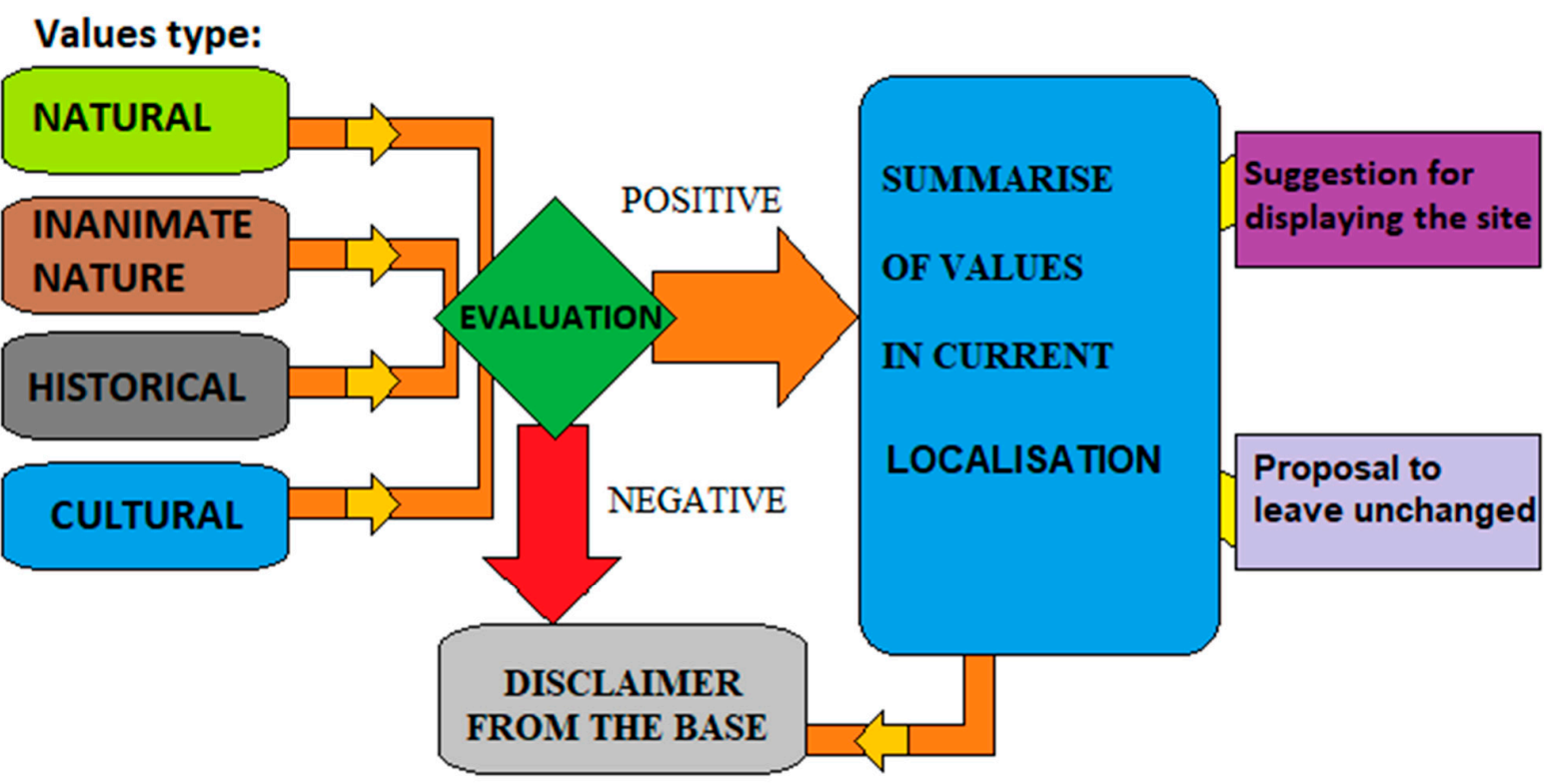

Figure 5. Diagram of site assessment in the described area.

In selecting the sites proposed in this study, the classification was based on the work of James-Williamson et al. [64], Williams [65], Woo et al. [66], Brilha [9,12], and Kubalíková [67], modifying them to local needs (Figure 5). In addition, we applied a Geosite Assessment Model (GAM) created by Vujičić et al. [68]. Once the sites were inventoried, they were evaluated, paying particular attention to factors such as natural values (presence of unconventional or valuable plant communities, etc.; Figures 4 and 6), inanimate nature values (nature of the substrate, rock formations and sediments of various origins), and historical values related to the discovery of the area and existing traces of past exploration. Landscape values were also assessed (geomorphological features, possibility of close and distant observation of various forms, and the view extending from the site). On this basis, the evaluation of values and their analysis were made. The analysis of the surveyed area made it possible to indicate 29 sites, the numerical evaluation of their values of which is given in Table 1 and the exact location in Table 2. The authors believe that the Monchegorsk intrusion could be part of a larger protected area, e.g., Khibiny (postulated in a publication in 2021 [69]) due to the nature of its values, which are ranked at the sixth level in the classification [70,71]. 


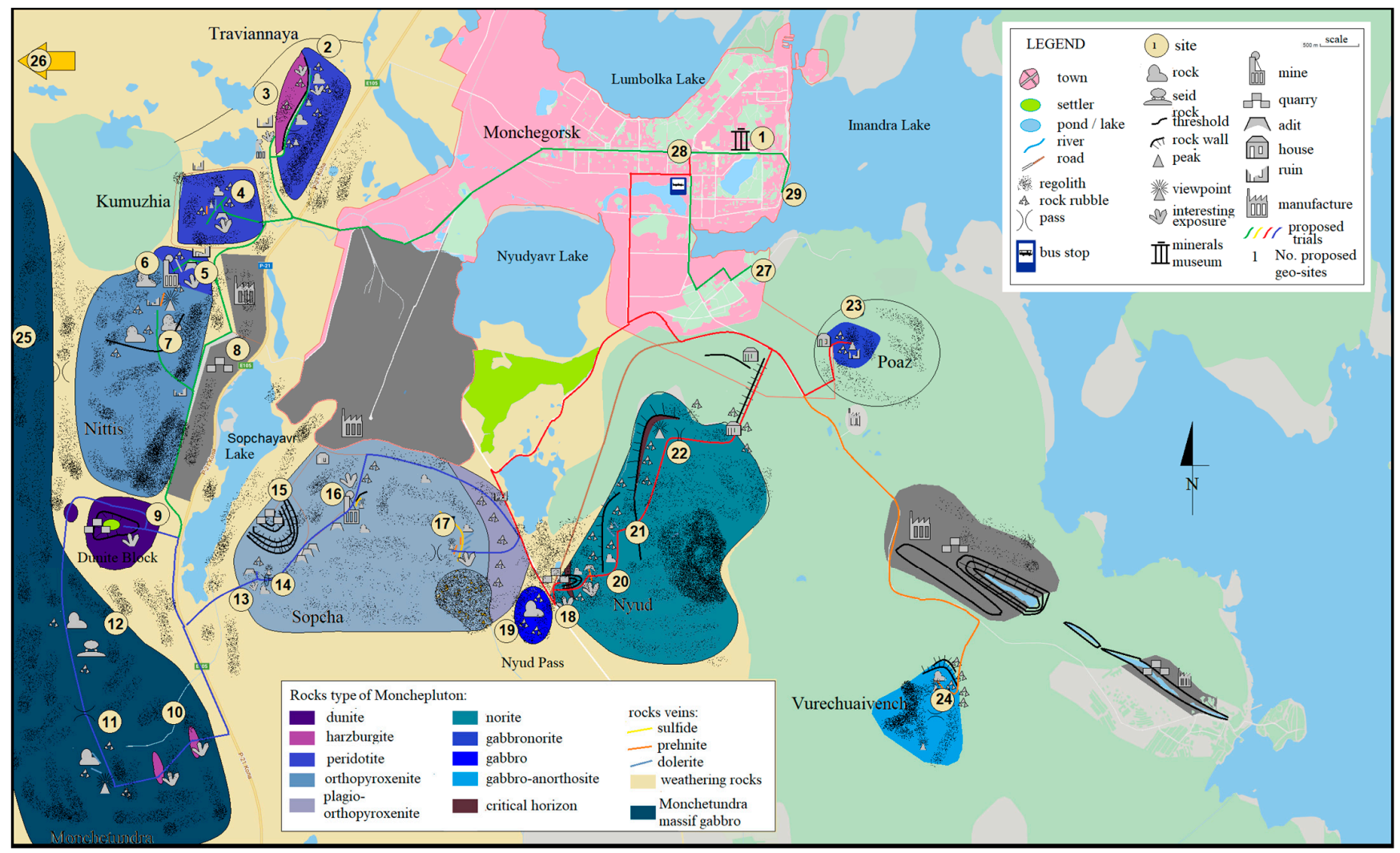

Figure 6. Schematic sketch of the Monchegorsk area and its tourist attractions.

Table 1. The results of the evaluation of values in proposed geo-sites *.

\begin{tabular}{|c|c|c|c|c|c|c|}
\hline & \multirow[b]{2}{*}{ Site Name } & \multicolumn{4}{|c|}{ Values Type } & \multirow[b]{2}{*}{ Total } \\
\hline & & Geology & Natural & Historical & $\begin{array}{c}\text { Inanimate } \\
\text { Nature }\end{array}$ & \\
\hline 1 & Monchegorsk museum & 1.0 & 1.0 & 1.0 & 0.0 & 3.0 \\
\hline 2 & East Traviannaya & 1.5 & 1.0 & 0.0 & 1.0 & 3.5 \\
\hline 3 & Traviannaya mine & 1.5 & 0.0 & 1.0 & 0.5 & 3.0 \\
\hline 4 & Kumuzhia & 1.5 & 1.0 & 0.0 & 0.5 & 3.0 \\
\hline 5 & N Nittis slopes & 1.0 & 1.0 & 0.0 & 0.5 & 2.5 \\
\hline 6 & Nittis mine & 1.5 & 0.0 & 1.0 & 0.0 & 2.5 \\
\hline 7 & Nittis peak & 1.0 & 1.0 & 0.0 & 1.0 & 3.0 \\
\hline 8 & E Nittis gravel pit & 0.5 & 0.0 & 0.0 & 0.0 & 0.5 \\
\hline 9 & Dunite block quarry & 1.5 & 0.0 & 0.5 & 0.5 & 2.5 \\
\hline 10 & Monchetundra quarry & 1.5 & 0.0 & 0.5 & 0.0 & 2.0 \\
\hline 11 & Monchetundra peak & 1.0 & 1.0 & 0.5 & 1.5 & 4.0 \\
\hline 12 & Monchetundra "seids" & 1.0 & 1.0 & 1.5 & 1.5 & 5.0 \\
\hline 13 & Sopcha mine & 0.5 & 0.0 & 1.0 & 0.0 & 1.5 \\
\hline 14 & W Sopcha peak & 1.0 & 1.0 & 0.0 & 1.0 & 3.0 \\
\hline 15 & N Sopcha quarry & 1.0 & 0.0 & 0.5 & 0.0 & 1.5 \\
\hline 16 & N Sopcha mine & 1.5 & 0.0 & 1.0 & 0.0 & 2.5 \\
\hline 17 & E Sopcha & 1.5 & 0.0 & 0.0 & 1.0 & 2.5 \\
\hline 18 & Nyud quarry & 1.5 & 0.0 & 0.5 & 0.0 & 2.0 \\
\hline 19 & Nyud pass & 1.0 & 1.0 & 0.0 & 0.5 & 2.5 \\
\hline 20 & Nyud shaft & 1.0 & 0.0 & 1.0 & 0.0 & 2.0 \\
\hline 21 & Nyud "terrace" & 1.5 & 0.0 & 0.0 & 1.0 & 2.5 \\
\hline 22 & Nyud peak & 1.0 & 1.0 & 0.0 & 1.0 & 3.0 \\
\hline 23 & Poaz & 1.0 & 1.0 & 0.0 & 1.0 & 3.0 \\
\hline 24 & Vurechuaivench & 0.5 & 1.0 & 0.0 & 1.0 & 2.5 \\
\hline 25 & Hippik peak & 1.0 & 1.5 & 0.0 & 1.5 & 4.0 \\
\hline
\end{tabular}


Table 1. Cont.

\begin{tabular}{lcccccc}
\hline & & \multicolumn{4}{c}{ Values Type } \\
\cline { 3 - 5 } & Site Name & Geology & Natural & Historical & $\begin{array}{c}\text { Inanimate } \\
\text { Nature }\end{array}$ & Total \\
\hline 26 & Vaikis waterfall & 1.0 & 1.5 & 0.0 & 1.5 & 4.0 \\
27 & Monchegorsk monastery & 0.0 & 0.5 & 0.5 & 0.0 & 1.0 \\
28 & Monchegorsk center & 0.0 & 0.0 & 0.5 & 0.0 & 0.5 \\
29 & Imandra Lake & 0.5 & 0.5 & 0.5 & 0.0 & 1.5 \\
\hline
\end{tabular}

* The number value characterizes the importance of a value from 0.0 (insignificant) to 1.00 (significant at the world level).

Table 2. List of sites in Monchegorsk.

\begin{tabular}{|c|c|c|c|}
\hline \multicolumn{2}{|c|}{ Site Name } & \multirow{2}{*}{$\begin{array}{c}\text { Longitude } \\
67^{\circ} 56^{\prime} 20.2^{\prime \prime} \mathrm{N}\end{array}$} & \multirow{2}{*}{$\begin{array}{c}\text { Latitude } \\
32^{\circ} 56^{\prime} 57.1^{\prime \prime} \mathrm{E}\end{array}$} \\
\hline 1 & Monchegorsk museum & & \\
\hline 2 & East Traviannaya & $67^{\circ} 56^{\prime} 43.7^{\prime \prime} \mathrm{N}$ & $32^{\circ} 49^{\prime} 01.2^{\prime \prime} \mathrm{E}$ \\
\hline 3 & Traviannaya mine & $67^{\circ} 56^{\prime} 32.9^{\prime \prime} \mathrm{N}$ & $32^{\circ} 48^{\prime} 11.5^{\prime \prime} \mathrm{E}$ \\
\hline 4 & Kumuzhia & $67^{\circ} 55^{\prime} 56.3^{\prime \prime} \mathrm{N}$ & $32^{\circ} 47^{\prime} 31.2^{\prime \prime} \mathrm{E}$ \\
\hline 5 & N Nittis slopes & $67^{\circ} 55^{\prime} 08.6^{\prime \prime} \mathrm{N}$ & $32^{\circ} 46^{\prime} 35.5^{\prime \prime} \mathrm{E}$ \\
\hline 6 & Nittis mine & $67^{\circ} 55^{\prime} 10.3^{\prime \prime} \mathrm{N}$ & $32^{\circ} 46^{\prime} 18.2^{\prime \prime} \mathrm{E}$ \\
\hline 7 & Nittis peak & $67^{\circ} 54^{\prime} 50.1^{\prime \prime} \mathrm{N}$ & $32^{\circ} 45^{\prime} 21.1^{\prime \prime} \mathrm{E}$ \\
\hline 8 & E Nittis gravel pit & $67^{\circ} 54^{\prime} 11.3^{\prime \prime} \mathrm{N}$ & $32^{\circ} 47^{\prime} 03.8^{\prime \prime} \mathrm{E}$ \\
\hline 9 & Dunite block quarry & $67^{\circ} 53^{\prime} 50.2^{\prime \prime} \mathrm{N}$ & $32^{\circ} 45^{\prime} 28.5^{\prime \prime} \mathrm{E}$ \\
\hline 10 & Monchetundra quarry & $67^{\circ} 51^{\prime} 59.6^{\prime \prime} \mathrm{N}$ & $32^{\circ} 45^{\prime} 15.8^{\prime \prime} \mathrm{E}$ \\
\hline 11 & Monchetundra peak & $67^{\circ} 52^{\prime} 11.9^{\prime \prime} \mathrm{N}$ & $32^{\circ} 44^{\prime} 40.2^{\prime \prime} \mathrm{E}$ \\
\hline 12 & Monchetundra seids & $67^{\circ} 52^{\prime} 23.3^{\prime \prime} \mathrm{N}$ & $32^{\circ} 44^{\prime} 33.2^{\prime \prime} \mathrm{E}$ \\
\hline 13 & Sopcha mine & $67^{\circ} 53^{\prime} 11.0^{\prime \prime} \mathrm{N}$ & $32^{\circ} 48^{\prime} 03.5^{\prime \prime} \mathrm{E}$ \\
\hline 14 & W Sopcha peak & $67^{\circ} 53^{\prime} 12.9^{\prime \prime} \mathrm{N}$ & $32^{\circ} 48^{\prime} 26.6^{\prime \prime} \mathrm{E}$ \\
\hline 15 & N Sopcha quarry & $67^{\circ} 53^{\prime} 32.6^{\prime \prime} \mathrm{N}$ & $32^{\circ} 48^{\prime} 30.1^{\prime \prime} \mathrm{E}$ \\
\hline 16 & N Sopcha mine & $67^{\circ} 53^{\prime} 17.6^{\prime \prime} \mathrm{N}$ & $32^{\circ} 50^{\prime} 05.3^{\prime \prime} \mathrm{E}$ \\
\hline 17 & E Sopcha & $67^{\circ} 53^{\prime} 35.7^{\prime \prime} \mathrm{N}$ & $32^{\circ} 51^{\prime} 42.9^{\prime \prime} \mathrm{E}$ \\
\hline 18 & Nyud quarry & $67^{\circ} 53^{\prime} 11.3^{\prime \prime} \mathrm{N}$ & $32^{\circ} 53^{\prime} 58.6^{\prime \prime} \mathrm{E}$ \\
\hline 19 & Nyud pass & $67^{\circ} 52^{\prime} 58.6^{\prime \prime} \mathrm{N}$ & $32^{\circ} 53^{\prime} 17.5^{\prime \prime} \mathrm{E}$ \\
\hline 20 & Nyud shaft & $67^{\circ} 53^{\prime} 15.2^{\prime \prime} \mathrm{N}$ & $32^{\circ} 54^{\prime} 40.2^{\prime \prime} \mathrm{E}$ \\
\hline 21 & Nyud "terrace" & $67^{\circ} 53^{\prime} 34.3^{\prime \prime} \mathrm{N}$ & $32^{\circ} 55^{\prime} 01.5^{\prime \prime} \mathrm{E}$ \\
\hline 22 & Nyud peak & $67^{\circ} 53^{\prime} 53.6^{\prime \prime} \mathrm{N}$ & $32^{\circ} 55^{\prime} 36.9^{\prime \prime} \mathrm{E}$ \\
\hline 23 & Poaz & $67^{\circ} 55^{\prime} 01.5^{\prime \prime} \mathrm{N}$ & $32^{\circ} 58^{\prime} 35.6^{\prime \prime} \mathrm{E}$ \\
\hline 24 & Vurechuaivench & $67^{\circ} 52^{\prime} 33.6^{\prime \prime} \mathrm{N}$ & $33^{\circ} 00^{\prime} 53.3^{\prime \prime} \mathrm{E}$ \\
\hline 25 & Hippik peak & $67^{\circ} 56^{\prime} 53.1^{\prime \prime} \mathrm{N}$ & $32^{\circ} 38^{\prime} 58.4^{\prime \prime} \mathrm{E}$ \\
\hline 26 & Vaikis waterfall & $68^{\circ} 01^{\prime} 35.9^{\prime \prime} \mathrm{N}$ & $32^{\circ} 26^{\prime} 45.0^{\prime \prime} \mathrm{E}$ \\
\hline 27 & Monchegorsk monastery & $67^{\circ} 55^{\prime} 34.5^{\prime \prime} \mathrm{N}$ & $32^{\circ} 57^{\prime} 42.1^{\prime \prime} \mathrm{E}$ \\
\hline 28 & Monchegorsk center & $67^{\circ} 56^{\prime} 09.0^{\prime \prime} \mathrm{N}$ & $32^{\circ} 55^{\prime} 55.6^{\prime \prime} \mathrm{E}$ \\
\hline 29 & Imandra Lake & $67^{\circ} 56^{\prime} 11.2^{\prime \prime} \mathrm{N}$ & $32^{\circ} 57^{\prime} 56.8^{\prime \prime} \mathrm{E}$ \\
\hline
\end{tabular}

Thin plate preparations were made from the rock samples and then they were examined using optical and electron microscopy techniques and other methods of modern geology. The studies were carried out in the Department of Geology, Geomorphology, and Geoinformation at the Institute of Earth and Environmental Sciences, Maria CurieSkłodowska University in Lublin (UMCS). Evaluation of botanical and environmental data was conducted at Murmansk Arctic State University (MAGU), with the cooperation of Lapland Nature Reserve. The evaluation of cultural and historical values was carried out at the Faculty of Humanities of UMCS and MAGU. Based on the analyses and assessments, the most interesting sites were selected and are described below (Table 1). The proposed routes were based on those features that, in the opinion of the authors, have outstanding qualities of at least several types. They were composed in such a way to optimally enable people to reach and visit the objects listed below. The discussed routes differ in length and scale of difficulty. This makes it possible for tourists with different requirements to visit the proposed sites and become acquainted with the discussed region. While describing 
individual sites, several solutions were proposed to increase social awareness of the value of the area among both residents and tourists.

\section{Results}

The discussed area is characterized by exceptional geological, natural, historical, and inanimate nature values. The evaluation values of these areas according to the evaluation method proposed by Tomić and Božić [23] (modified for this text) are listed above in Table 1. The values described in this table are the sum of various qualities such as geological values (rocks formations, mineralization, faults and nature of the substrate), natural values (presence of unconventional or valuable plant communities, etc.; Figures 4 and 6), inanimate nature values (geomorphological features, possibility of close and distant observation of various forms, and the view extending from the site), and historical values related to the discovery of the area and existing traces of past exploration.

By analyzing the data in Table 1, it is possible to identify the sites with the highest and lowest scores for each value. Monchetundra seids (site 12), Vaikis waterfall (site 26), Hippik Peak (site 25), Monchetundra Peak (site 11), and East Traviannaya (site 2) have the highest values. In the case of the former site, it is characterized by unique geological values and is also associated with historical heritage (power stones). These sites are also generally located in areas of good exposure from where there is a view of a large area. Vaikis waterfall is the highest in the region. This waterfall is situated in a picturesque place, formed on a rock shelf. The examples of plants that are found there are also interesting, and they are the species described in the Red Book of Murmansk District [62,63]. The area around Hippik, the highest peak in the region, is notable for its scenic character and the various rocks (bedrock and erratics) found there. The same is true for Monchetundra Peak, where, in addition to notable geology and scenic qualities, Arctic vegetation can also be observed. Moreover, in the vicinity of Monchetundra, there are historical heritage monuments connected with Saami activity (reindeer catching pits in the area of Chuna Lake). The East Traviannaya area contains highly rated geological features, as it is a region of ultramafic and basic rocks. There are numerous xenoliths with interesting mineralization in addition to tectonic formations and mineral veins and associated secondary mineralization. Apart from these values, this peak is relatively easy to overcome and has great landscape values. On the western side, it is overgrown with forest transitioning into tundra. The lowest rated is the E Nittis gravel pit (site 8), an active site that mines fossilized glacial sediments. Apart from some geological values (interesting erratics, postglacial sediments), it is not very intriguing. It was included mainly because the shortest way to Nittis passes by it, and also due to the possibility of seeing post-glacial sediments in the form of fresh exposures. Other sites include the center of Monchegorsk (site 28).

This site was included because of the beginning and end of the proposed routes and connections from this region. The town has relatively new buildings from the second half of the 20th century. Another included site is Monchegorsk Monastery (site 27), although this site is relatively new (built in the late 20th and early 21st centuries), this place is noteworthy for its cultural values and its location on the slope of Poaz above the city by the lake, which makes it well visible from a distance. From the point of view of geological values, the highest-rated were East Traviannaya (described above), Traviannaya mine, Nayud "terrace", E Sopcha, N Sopcha mine, Nyud quarry, Nittis mine, Dunite block quarry and Monchetundra quarry. These sites are very important for understanding the key geological features of the area (faults, exposures, different rock types, mineralization, and secondary processes). Rare rocks can be seen there along with sulfide, PGE, and oxide mineralization. In addition to geological values, many of these objects were also highly rated due to historical mining infrastructure objects and noteworthy forms of inanimate nature (landscape values). In the case of natural values, the area of Hippik peak and Vaikis waterfall was rated highest due to interesting vegetation including rare and protected species. From the point of view of historical values, the highest marks were given to the already mentioned Monchetundra seids and several objects connected with the heritage of 
the history of exploration and exploitation of the area (Traviannaya mine, N Sopcha mine, Nittis mine, Nyud shaft, Sopcha mine). The Monchegorsk museum was also highly rated due to the exhibits found there. This museum is a place that a tourist should visit if he is interested in the environment, nature, mineralogy, and history of the area.

\section{Route Proposal}

The entire route has been divided into several sections independent of each other: from the City Centre to the NKT massifs ( $26 \mathrm{~km}$, Tables 2 and 3), Dunite Bock-Monchetundra Peak $(7 \mathrm{~km})$, and Sopcha-Nyud-Poaz $(7.6 \mathrm{~km})$, with possible access to Vurechuaivench $(6 \mathrm{~km})$. Below is a detailed description of the routes. Monchegorsk-MonchetundraHippik-Vaikis-Monchegorsk is a separate route, as it is about $72.5 \mathrm{~km}$ long and should be done with proper preparation (tent, provisions). Individual massifs and the city of Monchegorsk will be discussed later in the article.

Table 3. Average time to reach each site.

\begin{tabular}{|c|c|c|c|c|c|c|c|}
\hline \multirow[t]{2}{*}{ Site } & \multirow{2}{*}{$\begin{array}{c}\text { Distance } \\
{[\mathrm{km}]}\end{array}$} & \multicolumn{2}{|c|}{ Average Time } & \multirow{2}{*}{ Site } & \multirow{2}{*}{$\begin{array}{c}\text { Distance } \\
{[\mathrm{km}]}\end{array}$} & \multicolumn{2}{|c|}{$\begin{array}{l}\text { Average Time } \\
\text { [minutes] }\end{array}$} \\
\hline & & On Foot & By Car & & & On Foot & By Car \\
\hline $28-1$ & 0.5 & 7 & 1 & $15-16$ & 0.6 & 20 & $* *$ \\
\hline $1-2$ & 6.5 & 92 & $9 *$ & $16-17$ & 2 & 60 & $* *$ \\
\hline $2-3$ & 0.5 & 30 & $* *$ & $13-17$ & 3 & 60 & $* *$ \\
\hline $3-4$ & 2 & 60 & $1 *$ & 17-19 & 1 & 60 & $* *$ \\
\hline $4-5$ & 1.5 & 40 & 1 * & $19-1$ & 7 & 95 & 7 \\
\hline $5-6$ & 1 & 60 & $* *$ & 19-18 & 0.6 & 10 & 2 \\
\hline $6-7$ & 1 & 90 & $* *$ & $19-20$ & 0.7 & 20 & $* *$ \\
\hline $7-8$ & 1.5 & 90 & $* *$ & $20-21$ & 0.9 & 25 & $* *$ \\
\hline $8-9$ & 1 & 20 & $1 *$ & $21-22$ & 0.8 & 30 & $* *$ \\
\hline $9-1$ & 12 & 200 & 12 * & $22-23$ & 2.5 & 50 & $* *$ \\
\hline $9-10$ & 3 & 50 & $2 *$ & $23-1$ & 4.5 & 60 & 8 \\
\hline $10-11$ & 3 & 60 & $* *$ & $23-24$ & 6 & 94 & $4^{*}$ \\
\hline $11-12$ & 0.5 & 20 & $* *$ & $24-1$ & 8.5 & 127 & 11 * \\
\hline $12-9$ & 3 & 45 & $* *$ & $12-25$ & 12 & 180 & $* *$ \\
\hline $1-10$ & 13.5 & 205 & 13 & $25-26$ & 15 & 255 & $* *$ \\
\hline $1-13$ & 12.5 & 180 & 12 * & $26-1$ & 30 & 500 & $14^{*}$ \\
\hline $12-13$ & 1.5 & 20 & 1 & $28-27$ & 2.7 & 33 & 7 \\
\hline 13-14 & 0.5 & 40 & $* *$ & $28-29$ & 1.3 & 17 & 3 \\
\hline $14-15$ & 0.6 & 30 & $* *$ & & & & \\
\hline
\end{tabular}

\section{City of Monchegorsk}

The city of Monchegorsk is located at the foot of the Monchetundra hills, which tower over the city in a picturesque way. It is also bounded by lakes Nyud, Lumbolka, and Imandra, in the vicinity of which it is located (Figure 6). An important road junctionMurmansk-St. Petersburg (with the possibility of connection with Finland and Norway) runs in the vicinity of the city. In Monchegorsk, numerous prospecting and processing plants deal with $\mathrm{Cu}-\mathrm{Fe}-\mathrm{Ni}$ ore. This city of fifty thousand people owes its establishment to nearby deposits of sulfide ores of these metals, which were discovered and made available during the interwar period [72,73]. In 1937, mines and processing plants were built to extract and process the ore [72,73]. The strict city center is built of brick houses in the neoclassical style. The town also has a mineral museum, which is the starting (and ending) point of the discussed tours. In the museum, various specimens of minerals and rocks occurring in the discussed massif can be found, along with numerous exhibits related to the indigenous people who inhabited the area.

In Monchegorsk, there is also a tourist base (object 28), hotels, restaurants, and a bus station from where one can get to Murmansk (to the north) or Apatity (to the south). There is also a waterfront to the east, allowing one to walk along the shores of Lake 
Imandra (object 29). It is the largest trough lake in the region and behind it there is a view of Khibiny, the highest mountain range in the region [37]. The Kafedral'nyy Sobor Vozneseniya Gospodnya Church (object 27) is also located in the vicinity.

\section{East Traviannaya}

The Traviannaya massif is located in the northern part of the NKT. This massif has a slightly different top line than the other blocks of the Monchepluton, which can be defined as WNW-ESE. It is very well visible from the St. Petersburg-MurmanskKirkenes/Rovaniemi road, which runs through the middle of the discussed intrusion, between the meridional and latitudinal wings. Ascending from the east, one passes a large part of weathering up to $2 / 3$ of the height of the peak covering the hill. Subsequently, single blocks of orthopyroxenites are exposed, weathered to a light green-gray color, which takes on rounded shapes. A large tectonic fracture filled with talc schist and dolerite dacite is visible in the summit area. This is where the transition to the Harzburgites, located in the western part of the hill, occurs. In the zone close to the fault, numerous smaller culm faults filled with talc and iron oxides are visible, staining the fault surfaces of the rocks pink (Figure 4B).

In the southwestern part of the slopes, a smooth transition of harzburgites to orthopyroxenites occurs. It is well visible in the weathered surface of these rocks, as the harzburgites from the Traviannaya area are weathered and covered with purple iron oxides (Figure $4 \mathrm{H}$ ). Further on, they form xenoliths in orthopyroxenites that are well readable due to their reddish surfaces, and lower resistance to weathering, hence they have more concave forms than the surrounding rocks (Figure $4 \mathrm{H}$ ). In contrast, in the harzburgite zone, xenoliths and scholars of dunites and chromitites appear. These makeup black inserts in the discussed rocks and are well readable in their weathered surfaces. The top of the hill also offers views of the surrounding town and nearby massifs, including Monchetundra (to the west). At the base of the hill is Lake Moncheozero. To the southwest, is a small mine, now closed-a testament to past exploration in the area.

The Traviannaya area lacks tourist infrastructure. In 2021, motocross roads were laid there (arbitrarily, without permission from the regional government), characterized by some rocks being spray-painted with road markings. This also increased the level of devastation of the place. Regardless of the purpose, these are the only markings in this massif at the moment.

\section{Traviannaya mine}

At the western foot of the mountain, there is an inactive mine called "shakhta no. 5.1" in the dumps of which one can see pyroxene cumulates containing sulfides transported from the interior of the mountain (Tables 2 and 3). These rocks sometimes have very large crystals up to several $\mathrm{cm}$ in size. Sulfide minerals are also visible in these rocks. In the area of the mine, there is a view of the discussed mountain and the valley separating the Traviannaya massif from Monchetundra. Further south, there is a saddle that forms a transition to the next massif -Kumuzhia (Figure 4A). There is an earth road that leads to the mine area. No signage exists leading to the former mine. At the mine site, the adit is buried and the buildings have been razed. There is a lot of rubble and heaps of rocks from the mine on the site.

4. The Kumuzhia Massif

Lying to the south of Traviannaya, the Kumuzhia Massif is almost completely covered by blocks of weathered rock, revealing the outcrops only in the peak areas. There, the orthopyroxenites more resistant to weathering are exposed. In the area of the discussed massif, there is a border of mixed harzburgite rocks with pyroxenites, but these rocks, being less resistant to weathering, are covered with a layer of alteration. In the peak part of Kumuzhia, weathered, grey-greenish orthopyroxenites are visible. On the eastern slopes of the massif, there is a small inactive mine with a heap of harzburgites containing sulfide mineralization. Even today, beautiful specimens of massive sulfide ore containing platinum and palladium minerals can be found $[37,54]$. In the upper part, dolerite dikes and much later prehnite veins are visible. The summit part of the massif offers an interesting view of 
the highest Nittis massif, towering over the others, and the town of Monchegorsk at the foot of Sopcha and Nyud, and the Monchetundra massif to the southwest and Lapland with its picturesque lakes and distant granulite massifs to the west. This massif is covered by a rare dwarf forest consisting mainly of birch (Betula betula), accompanied by spruce (Pinus silvestris) and occasionally single juniper bushes (Juniperus L.). Lapland willow (Salix lapponum) grows in the vicinity of streams. This forest is an example of succession in areas previously devoid of it due to anthropogenic activities (logging and acid rain). Moving from Kumuzhia to the Nittis, at the foot of these mountains, there is a fragment of a processing plant from the first half of the 20th century, with partially destroyed railroad ramps, sorting plants, and spoil heaps mixed with the Nittis stone.

5. N Nittis slopes

Continuing south, it reaches the Nittis massif, which towers over all the Monchepluton hills. Walking from the north, one passes a processing plant and the remains of a stone grinding plant where one can still admire numerous blocks of various rocks from the Murmansk area. Climbing further up to the summit area, one can see numerous rock formations forming small walls and gullies, eagerly used by climbers for training purposes.

Higher up there is an outcrop of a hematite-magnetite vein with sulfides, which can be seen if one is careful not to fall into the shaft. Ascending the slopes of this massif, one can admire the panorama of the town of Monchegorsk (from the east) and the Monchetundra region (from the west), which at this point approaches Nittis, creating a pass between these two massifs. Further south, zones of natural weathering are also visible in the Dunite block chromitite rocks, which take on an ochre color. These rocks are beneath weathered, blocky, postglacial sediments (Figure 4F). In the case of this massif, the lack of tourist infrastructure is a serious problem. Open adits and shafts may pose danger. This massif lacks adequate exposure of its scenic, geological and historical qualities and protection against further destruction. There are numerous blocks on the slopes, especially in the area of the former loading ramp located on the slope. Higher up there are stone runs, also unprotected. At present, at the north-eastern foot of the slope climbing routes are marked out and above them, motocross routes are marked out (unauthorized, without the consent of the regional authorities). The latter disfigure the area with spray-painted signs and damage caused by motorcycle riding. However, at the moment these are the only markings in the area.

6. Nittis mine

This site is located on the northeastern slopes of the Nittis Massif. It is a disused mine with a shaft visible from a distance. The property is an important monument to the mining history of the area. Currently, this mine is inactive, poorly secured, and the feeling of a breeze means that it is still passable in some parts. There are numerous orthopyroxenites and olivine orthopyroxenites with sulfide ore in the vicinity of the mine in question, which indicate the purpose of the plant construction at this location. In this place, a rare sprucebirch forest gives way to forest-tundra in which dwarf birch (Betula nana) and Lapland willow (Salix lapponum) appear at this altitude. Lapland poppy (Papaver lapponica), octopetal oak (Dryas octopetala), and numerous mosses and lichens are visible at higher elevations in the tundra zone.

\section{Nittis peak}

As one ascends to the summit of Nittis, the slope of the hill becomes steeper as the rocks are composed mainly of orthopyroxenites somewhat more resistant to weathering than the peridotite rocks. As one approaches the summit area, one can find numerous traces of ore prospecting at this location. There are ditches, pits and small prospecting shafts dug, today completely buried. On the summit, there is a building of the no longer operating chairlift, where you can take shelter from the rain and wind. In the summit parts, one can see discoloration of the pyroxenites, marked by the greening of the rocks, and then the occurrence of white-cream veins. These are prehnite and calcite mineral veins that contribute to local petrological changes in the rocks. From here, there is a picturesque view of all the massifs and hills of the Monchepluton and Monchetundra intrusions, and the Khibiny Massif and Lake Imandra and the town of Monchegorsk below. To the west, one 
can see the distant horizons of the Lapland hills. From the summit of Nittis, the proposed route goes towards the summit of Hippik in the Monchetrundra massif, and a connecting route to Sopcha is suggested through the exposures in the southern part from Nittis. The descent from the summit towards the south can be continued following the line of the lift that used to run to the foot of the mountain from its southern sides. In the discussed massif, the tourist infrastructure has been seriously devastated. Still, the existing buildings of the ski lift could serve as shelter in the future (they can be easily adapted at little cost). There is a lack of marked hiking trails and information about the former exploration work conducted here.

8. Gravel pit

Sopche yavr, a small trough lake, extends from the west below the summit of Nittis, with ramparts of postglacial sediments rising above it (Figure 6). They are exposed in a gravel pit (object no. 8), which is located directly in the vicinity of the St. PetersburgMurmansk road. In the gravel pit and in its vicinity one can see fluvioglacial formations and a variety of weathered rock boulders. On the eastern side of the valley, closer to the Sopcha massif, the buildings of the processing plant can be seen, which deal with the smelting of ores currently delivered from other locations. Continuing along the road to the south, one encounters the now-defunct dunite and chromitite quarry at Dunite block.

9. Dunite block quarry

In this quarry, the towering Nittis and Monchetundra massifs can be observed from the east. It is made up of several levels, three of which are above the water table of a small reservoir that fills the flooded levels. The water in this reservoir is acidified, due to the presence of numerous metal ores in the rocks in question. The quarry exposes a sequence of rocks with dunites, harzburgites and lherzolites, and massive chromitites that can be observed in the levels that are not flooded by water. These rocks are rhythmically over stratified (Figure 4A). The geological value of this quarry is important because of the origin of these rocks. They are thought to have been formed by secondary injection of primitive magma during the solidification of the Monchepluton. At this point, the proposed route turns to the east and after crossing the valley, it climbs to the Sopcha massif. It is also possible to pass along this route towards the Monchetundra Mountains, where the gabbroanorthosites of this massif are already exposed. The quarry lacks tourist infrastructure. Unprotected mining levels located directly above the reservoir pose a danger of slipping and falling into the water

10. Monchetundra quarry

In the Monchetundra area at the foot of the mountain, there are springs with drinking water, which are readily taken by the inhabitants of the nearby town. Above, numerous quarries of an exploratory nature are encountered along the earth road. There are small vein rocks composed of peridotites that cut through the gabbronorites. The road climbs scenically up the slopes of the mountain without reaching the summit. Above the road, a boulder field and a rock block belong to the discussed massif. The infrastructure in this area is poor. The road in question belongs to the network of technical, earthen roads, which are located in the discussed region due to the conducted prospecting works. The road is unmarked, although it is well visible from the foot of the mountain. It ends without reaching the summit of Monchetundra. The last $500 \mathrm{~m}$ of ascent you have to overcome on an unprotected block field. The stone-run rocks consist of multi-ton blocks that are difficult to walk on and easy to get stuck in.

11. Monchetundra peak

There is a triangulation pole in the summit area that can be used as a landmark during the expedition. It also makes it easier to find the summit culmination. It offers a view of the Monchepluton massif and many peaks on the Sami side to the west. The place has many scenic, historical, natural, and geological values. However, there is currently a lack of tourist infrastructure in place. A platform with information boards would be useful, and access to the stone run should be secured by building a ramp. Near the summit on the west side is Chuna Lake, where there are pits built by the Saami for catching reindeer. On 
the west and north sides of the summit, there are numerous rocky thresholds and ponds with vegetation characteristic of arctic zones. There are Eriophorum angustifolium, Papawer lapponika, and numerous mosses and lichens.

12. Monchetundra "seids"

Further north from Monchetundra Peak, towards Hippik Peak in the eastern slopes of the mountain "seids", or large boulders (Figure 4E), are visible. Access to this site is currently unmarked; the lack of any trails makes it difficult to reach this site, which can be easily missed from a distance. The origin of these "seids" is unclear. Indigenous people believe that they were created in prehistoric times by human action, as the socalled "power stones", which were worshipped by them $[5,6]$. Others believe that the blocks were suspended in ice during glaciation and settled on smaller rocks during deglaciation. Regardless of the truth of these claims, these are very picturesque places, as some of the blocks weigh several tons. In the area of some hotels (e.g., in Murmansk) or along main roads, one can indeed find several similar smaller replicas, now made with the use of a crane, but they are usually not as interesting as the original blocks, which are often much larger and located in more picturesque places. Further north is Hippik Peak (Site 25), $965 \mathrm{~m}$ above sea level, the highest in the region, and on its northern slopes is the Vaikis Waterfall (Site 26).

13. Sopcha mine

The Sopcha massif has the shape of a truncated cone with two culminations, the higher western and the lower eastern, between which there is a small glacial depression. On most of the mountain, except for the top parts, it is covered with blocks of stone. On the western slopes of the mountain is an adit tapping into the olivine orthopyroxenites with sulfide ore. These rocks are accessible in a heap lying nearby. The adit itself is currently backfilled. Access to the adit from the road is difficult because the bottom of the valley has numerous small watercourses, swamps, and glacial deposits. The lack of marked trails in this place makes it necessary to walk on difficult terrain covered with sparse forest. Above the adit, one encounters the boulder fields of the peak Sopcha. This is a dangerous area because of the large angle of inclination of the slopes. Above them, there are numerous rock shelves and glacial outcrops built of orthopyroxenite. The lack of a marked trail in this massif can create a danger of sliding down the slope into an abyss.

14. W Sopcha peak

In the upper parts of W Sopcha, the slope is covered by a stone run of orthopyroxenites and in the highest parts, small xenoliths of harzburgites are visible. These are dark green against the background of light orthopyroxenites. In the place where these rocks are exposed, the sloping ridge is broken and a small fault line is noticeable. The rocks, the xenoliths of which are visible, belong to the so-called "313 horizons", a zone of secondary injection of the primary solution into the solidifying rocks of the massif. It surrounds the peak and is visible from a distance in the form of a ring of rocks with a reddish hue from the weathering of dispersed sulfides in them. Going towards the second peak of Sopcha from the east, one passes through a small plateau with numerous dolerite outcroppings. On the summit, one can admire a panorama of the surroundings-including the town of Monchegorsk (Figure 4B).

15. N Sopcha quarry

There is a large quarry on the north side of Sopcha that was involved in the mining of orthopyroxenites. This quarry has several mining levels and makes it possible to observe the layout of the rocks building the Sopcha massif from the north. Next to the quarry, there are also adits in various states of repair and heaps of rocks that originate from these adits. The whole complex is of great geological value in terms of showing the system of rocks in the discussed massif, and historical value from the point of view of the mining infrastructure. Further to the north, there is an active smelter of non-ferrous metals and a settling pond with a turquoise color of the lake due to the high $\mathrm{pH}$ of the water. Access to this settling pond and plant is impossible because of the fence located 
there. On the northern slopes of the mountain, there is a technical dirt road that allows access to the quarry.

16. N Sopcha mine

The northern slopes of Sopcha contain numerous shafts with olivine orthopyroxenites and sulfide ore and sulfide-bearing mylonites. Slightly farther away, a small mine with a shaft is visible, also routed to the sulfide rocks discussed. There are many rocks from this mine nearby. The discussed place is interesting because of the geological structure of the massif. It is still possible to find massive ore with platinum minerals, and in the orthopyroxenite rocks it is also possible to trace the sulfide mineralization. In mylonites, one can see olivines. Next to these rocks in the weathered slope, there are erratics that are a cross-section of various magmatic and metamorphic rocks with interesting structures. The site is accessible by an unpaved earth road and is relatively easy to reach, being located above the N Sopcha quarry described above (site 15). There are no information plaques that inform tourists about the value of the site. In the northern direction, one can observe the panorama of the town and the post-industrail landscape of this area.

\section{E Sopcha}

Sopcha massif has two culminations. The eastern one is situated about one kilometer from the western one. The summit zone has a gentle depression in the central part, probably from a small glacier that may have been here. In the eastern accumulation, orthopyroxenites are exposed, and numerous dolerite and lamprophyre veins. In the culmination itself, there are a series of prehnite veins discussed also at the Nittis massif (site 7). The orthopyroxenite rocks of Sopcha have a small share of plagioclase that increases towards the east. The next culmination - the Nyud massif (site 22) is built predominantly of norites. In the slopes of E Sopcha, various monadnock forms form single rocks and rock thresholds, and sometimes the hollows in these blocks are filled with small ponds. The variety of geomorphological forms in this area is great. From the summit, a view of Monchegorsk, Imandra Lake (to the east), and the other Monchepluton and Monchetundra massifs is revealed. In the discussed massif there is no tourist infrastructure. There is a need to mark the trails and to build information boards. On the summit, it is possible to put up a shelter against rain and wind. 18. Nyud quarry

To the east of Sopcha is the Nyud massif, covered on the east and south sides with pine and spruce forest, which changes into tundra above. Ascending towards the Nyud summit from the west, its northwestern slopes show slope breaks resulting from changes in the lithology of the massif. The western foothills are cut by the large, inactive Nyud II quarry, with several mining levels and numerous traces of drilling. The rocks that make up the quarry are classified as magmatic autobreccia of the so-called "critical horizon", also containing xenoliths of supracrustal rocks and numerous mineral veins of massive sulfides. There are several mining levels in the quarry and the quarry overlooks the work areas themselves and the Nyud slopes. The quarry is now closed, but interesting specimens of xenoliths, the sulfide ore, and other rocks can still be found there. Near the quarry, there is an earth road leading to the highest exploitation levels. Above the quarry, there are trails for trails and skiing. They are marked and visible (Figure 7).

19. Nyud pass

In the valley floor separating Nyud from Sopcha, there is an old asphalt road towards Monchegorsk, which is followed by the proposed route. In the vicinity of this road, gabbro is exposed in the form of individual blocks (Figure 4D). Numerous weathering formations are also visible, and a sparse forest composed mainly of pine and birch. 


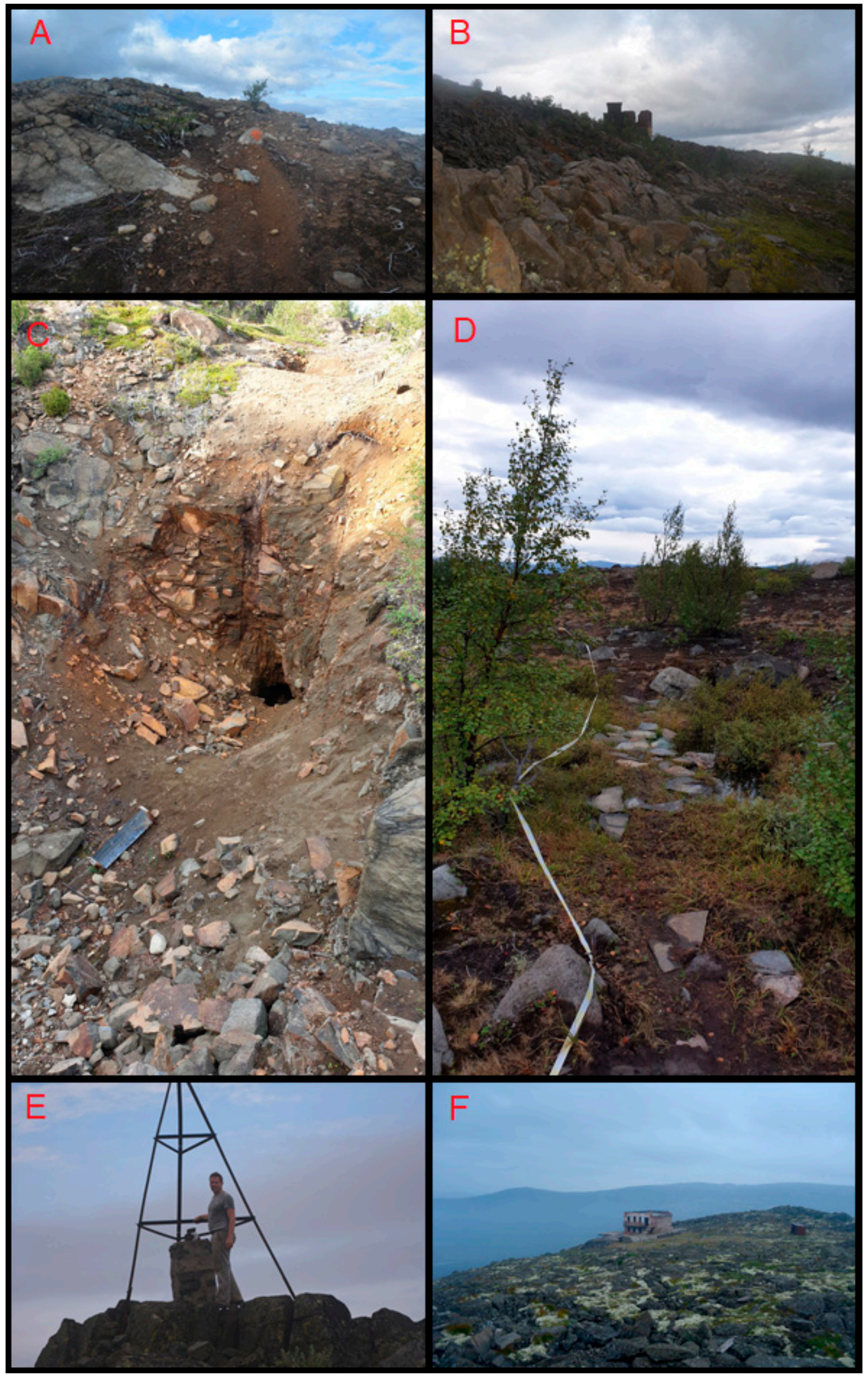

Figure 7. Examples of existing "infrastructure" in the area: markings of illegal motocross trails (A), left over mining infrastructure (B), unprotected adits (C), bicycle trail markings (D), triangulation patch (E), and a disused ski lift (F). 


\section{Nyud shaft}

Above this quarry, the western slopes of Nyud expose olivine norites that are often porphyritic in character, with large clinopyroxene grains several centimeters thick, in weathering rocks visible on their surface. The outcrops of these rocks form spur forms several meters high, which are worth seeing. Above them, there is a small break in the slope with former mining works exposed (shafts, adits), among which orthopyroxenites with dispersed sulfide mineralization are visible. The above-mentioned bicycle and skiing trails are located near these places. However, these trails lack information on what rock formations they pass through.

21. Nyud "Terrace"

Above the drifts in question, porphyry olivine norites are found. These rocks also exhibit rhythmicity resulting from the different proportions of orthopyroxenes. Slightly higher, there is another morphological break manifested by the occurrence of massive pyroxenites and accompanying rocks forming the critical horizon in question. This collapse is called a "terrasse" and covers a significant part of the slope, surrounding it with a ring and also exposing itself in its various parts from the other sides. Above it, the slope sharpens considerably, with the weathering rocks taking on a spotted reddish color. There is no tourist infrastructure in this area, but because of the landscape and geological values, it is a unique place.

22. Nyud Peak

The summit of Nyud is formed by massive norites cut into numerous valleys. On the eastern side, the massif is covered by a spruce-pine forest with secondary birch tree growth. The flattening visible on this side of the mountain may indicate the existence of a small glacier in the past. There is a chairlift on the north-western side of the mountain, which is accompanied by a small ski slope. The chairlift operates only in winter when the mountains are covered with snow.

\section{Poaz}

The Poaz massif, lying further east, is much lower than the previously described ones. Exposed rocks building this massif are classified as gabbroic with a massive character. This massif is almost completely covered with forest. In its top part, there is a television transmitter station with an earth road leading to it. In the upper parts of the hill, there is a view of all the previously passed Monchepluton peaks and the Monchetundra further on. There is a church (site 27) on the north side of the slopes of the massif.

\section{Vurechuaivench}

This peak is the most southeastern one. It is almost entirely covered with forest, and in its upper parts, the forest changes into tundra and alpine scree. The massif has two culminations: north-eastern and south-western, between which there is a plateau that was probably occupied in the past by small glaciers. The massif is composed of metamorphosed gabbroanorthosites (amphibolites). Numerous bedrocks, rock veins made of quartz and feldspar, and weathering covering the rocks are visible in its upper part. The weathering contains erratics in the form of blocks of magmatic and metamorphic rocks. From this site, there is a nice view of Lake Imandra on the eastern side and further-Chibiny, the highest mountain massif in the Kola Peninsula area (Figure 4C). The massif in question lacks tourist infrastructure, including any roads or paths. An additional danger due to the further presence of this massif from the town is the possibility of meeting a brown bear.

25. Hippik Peak

In the Monchetundra massif, the proposed route climbs towards the rosette-like summit of Hippik. The rocks passed on the way are gabbronorites having large crystals of plagioclase. In the southern slopes, numerous dolerites and olivine pyroxenites are visible. Above this zone is the Monchetundra peak with a sweeping view of the Imandra Belt hills-Varzuga in the south and the Chuna Tundra massif in the west. There are numerous rock outcrops, small ponds, and large blocks of rock lying on top of smaller ones called "seid" along the road towards the summit area of Hippk. The summit rises to an altitude of $965 \mathrm{~m}$ a.s.l., which is one of the highest elevations in the Murmansk district after the 
Khibiny and Lovozero massifs to the east beyond the shores of Lake Imandra. The area belongs to Lapland Nature Reserve and at the moment there are no marked hiking trails.

26. Vaikis waterfall

Further to the northeast, the slopes of the Monchetundra massif become gentler and a stream flows in the bottom of the valley, which on the north side has numerous rocky thresholds and a waterfall called Vaikis, which is the highest in Murmansk district. This area is undercut by steep slopes probably formed during glaciation. Below the waterfall, there is a lake of the same name. The height of the first cascade is about $40 \mathrm{~m}$, followed by several smaller cascades, whose total height is about $100 \mathrm{~m}$. The gorge below the first cascade is formed by steep rocks with well-defined ledges, which in their outlines resemble an ancient amphitheater. The cliffs protect the waterfall from the sun's rays, which is why there is a very long period of snow at the foot, which melts only at the beginning of August. The slopes of the gorge are so steep that only a person in good physical condition can go down to the bowl of the waterfall, it is impossible to enter the bowl of the first cascade from the lower part of the stream. At the foot of the waterfall, there are plants included in the Red Book of the Murmansk Region, in particular [62,63], on the rock shelves there is sedum Saxifraga foliolosa $\mathrm{R}$. Br. (Figure 8). The whole area of the lake belongs to the Lapland Nature Reserve and from the rocky threshold, there is a picturesque view of the lake and the Volcha Tundra and Lapland peaks further to the east. At the moment there are no marked hiking trails, only paths trodden by tourists.

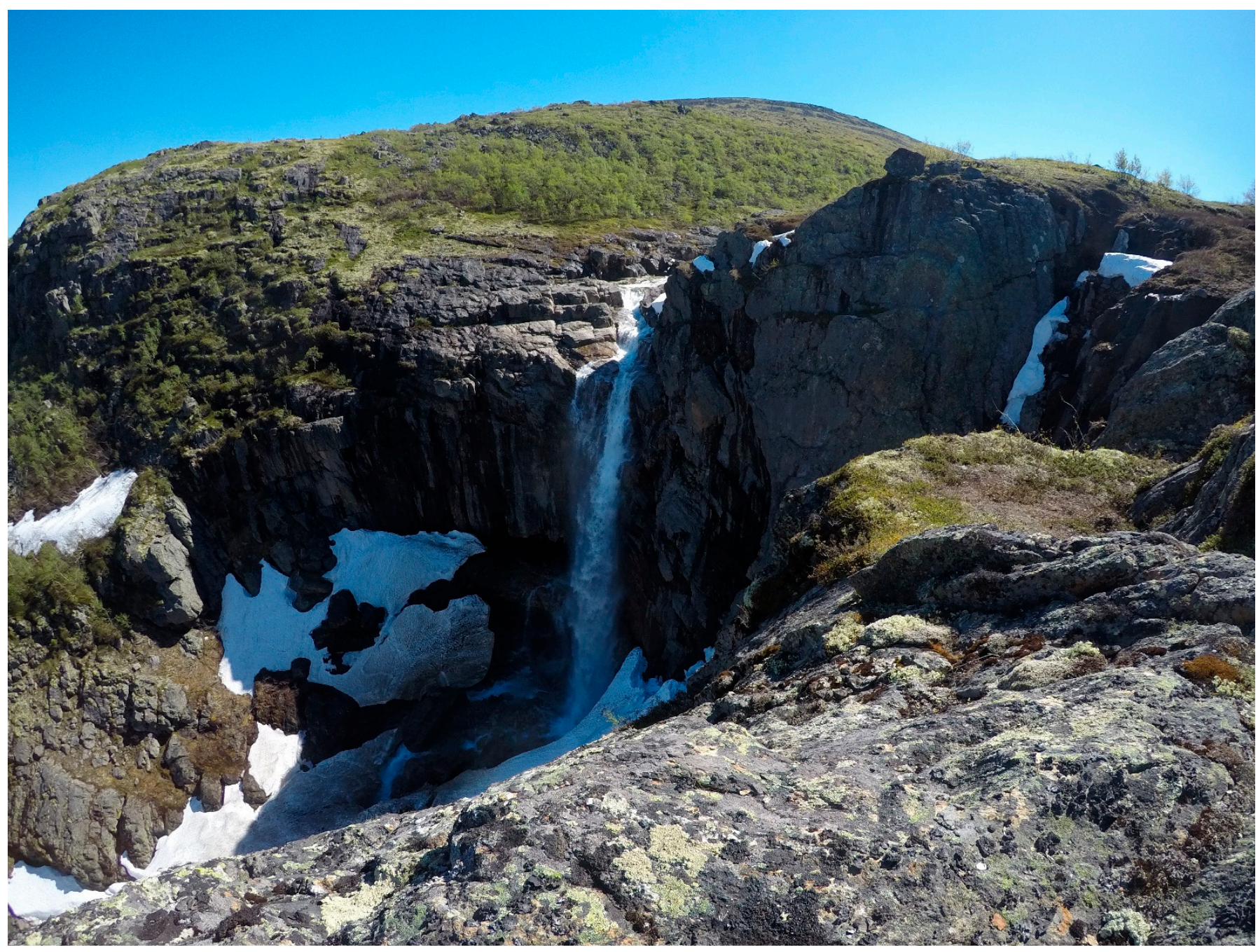

Figure 8. The view of Vaikis waterfall. 


\section{Monchegorsk Monastery}

The Cathedral of the Ascension of the Lord in Monchegorsk was built in 1997, relatively recently, but its location makes it well visible from the mountains and from the city [56]. It is a small church with a brick bell tower modeled on medieval churches preserved in central Russia. The highlight is the gilded tower above the central nave, ending in a cross. Its interior is decorated with numerous frescos and an iconostasis.

28. Monchegorsk center

There is a square in the center of the city where festivals and important holidays are held. There is also a bus station in the center, allowing people to get to Monchegorsk from the Murmansk region or other nearby towns. The streets in the center are surrounded by houses built mainly in the early 20th century, some of them in a neoclassical style and some in an eclectic style.

\section{Imandra Lake}

On the eastern side of the city, there is a boulevard on the shores of Imandra Lake. It is a trough lake $120 \mathrm{~km}$ long, the longest in Murmansk District, and is the natural boundary separating Lapland in the west from the Kola Peninsula in the east. The lake has an area of 876 square kilometers, with a depth of $67 \mathrm{~m}$ at its deepest point and numerous islands within its boundaries. It is a picturesque lake where one can enjoy the view of Khibiny, a mountain massif located in the central part of Murmansk District.

The proposed sites and the route shown in Figure 6 allow us to become acquainted with many aspects of the heritage of the Monchegorsk area. These sites and the proposed route, due to the distances between them (Table 2), can be trekked in a few days. The sites located in the area of Lapland Nature Reserve (site 25, 26) require additional permission from the park authorities to visit. At the moment the tourist infrastructure of this region is residual. The existing infrastructure facilities described above are far from being sufficient. The discussion below proposes solutions implemented in other similar sites.

\section{Discussion}

The proposed route in the discussed area is an interesting example of diverse geomorphological, geological and cultural forms, combined with picturesque views, post-mining infrastructure from the first and second half of the 20th century [6-8], and interesting flora $[32,63]$. Undoubtedly a great attraction, the only one of its kind, is the opportunity to see up close the ultra-basic and alkaline rocks forming large, relatively large hills near the city. Moving through the discussed Monchepluton and Monchetundra intrusions, one can observe a variety of existing land conservation forms from the National Park in the Monchetundra area through its buffer zone, reclamation zones and post-industrail pits [4]. The diversity and storied nature of the vegetation can be observed, and its secondary succession on post-mining areas. The observation of land reclamation makes it possible to run ecological and didactic trails $[19,74-76]$. Thanks to this, it is possible to shape an ecological attitude and promote environmental protection among both residents and tourists [77-80]. In important places, the access times provided will allow the hiker to prepare for exploring the trail [79-81].

At present, there are numerous earth roads on which one can move while visiting the area. However, the area deserves to be cleaned up to get rid of the objects that are not significant at present and to preserve those that are testiment to the intensive exploration and mining past [6-8]. The existing infrastructure in the form of active ski lifts indicates the tourist demand in this area and the possibility of development [7]. The inactive ski lifts on Nittis are slated to be renovated and in the area of the town, much more tourists are starting to appear. The location of the area in the vicinity of the St. Petersburg-Murmansk-Kirkenes road, which provides a good connection and an opportunity to draw the attention of passing motorists to the unique qualities of the area, is undoubtedly an important factor. An interesting proposal would be to rebuild a station on the Nittis railroad, allowing shelter for tourists and providing exceptional views of the area. The area has great potential and is worth paying attention to. It is also very important to build tourist infrastructure in the 
area, to mark trails, to increase the safety of tourists on the trails, and to be able to monitor places important from the point of view of safety [81-84]. These basic elements of tourist infrastructure require relatively small financial outlays, and significantly increase the level of safety in the mountains. In the long run, they can be extended with viewing platforms, trail development, and the creation of shelters-especially important in places distant from the city so as to allow for organizing further hikes beyond the indicated route and the opportunity to get to know this beautiful landscape [85-87].

\section{Proposal for Development of Tourist Infrastructure}

The discussed tourist route allows visitors to be exposed to and familiarize themselves with the eco- and geotourist landscape forms in the surrounding Monchegorsk hills. However, the route itself without infrastructure is not an attraction for a tourist and may even cause the would-be tourist to become lost or fall into disused mine shafts. The most basic enhancements are the addition of tourist signs painted on the rocks or marked on poles, hence allowing tourists to confidently walk the route. In a subsequent stage of development, the safety of the tourist and the possibility of observing interesting places should be ensured by building bridges, better routes, viewing platforms, and fencing off disused shafts and adits, etc. This is especially true for the former mining works where proper protection guarantees the safety of the tourist [86]. Such solutions can be built permanently allowing safe travel and the ability to take in areas of significance. Protection and monitoring of the former mining infrastructure against further destruction and unqualified visiting is an important element of increasing safety on the trail. Monitoring of a trail allows a tourist to observe weather conditions in places he or she plans to visit, to prepare for this stage, and to provide services with the possibility of assistance and reaction to difficult situations in the mountains should intervention be needed. The construction of Internet portals allows us to provide information about various objects and inform the tourist in other languages about important and interesting places passed on the trail [81]. This portal has the possibility to redirect the tourist to the proffered information about a given object using QR codes placed on information boards or small posts on the trail $[80,87]$. Such actions do not require any financial outlays and significantly increase the safety and quality of the experience. In the long run, the lift to the Nittis mountain could be restored, and perhaps extended to the Hippik slopes, allowing for the safe movement of tourists in the discussed area and at the same time enabling them to take in the scenic vistas from the discussed places. Such actions are necessary to increase the safety of tourists, to enable them to rest, eat and admire the landscape without fear of the weather breakdown or overexertion.

The problem of geoconservation is a well-known issue in the world. There are many examples of post-mining areas whose values have been appreciated as a form of geodesy [19,22]. Prosser [88], in his work, mentions the procedures of leaving and protecting excavations as an example of creating natural exposures that make it possible to learn about the geological structure of the area. In turn, Sa dos Santos et al. [89] point to the educational character of the old excavations, after their adaptation of exploration and enrichment with elements that stimulate imagination in children. Monchepluton is a place associated with the breakup of the supercontinent Kenorland. It is where Europe began. It offers many possibilities to show the early history of Earth and the emergence of life on Earth. This goal can be achieved by in situ and ex situ exposition of rock samples as mentioned by Burek [90]. The work of Kubalíková [67] devotes a great deal to the problem of evaluating geodiversity assets such as those described in the Monchepluton example. An important need to protect the discussed massifs is connected with the threat left by the abandoned post-mining area, the processes of uncontrolled erosion and destruction of the object through its devastation. This area can be very attractive for tourists visiting Murmansk Region [2]. Considering the location of the massifs along the international road and the proximity of the city of Monchegorsk with its tourist facilities, at little expense and with the application of appropriate information techniques, the touristic potential 
of the area will be greatly enhanced [20,25]. Murmansk District region has been popular for several years, and the number of tourists visiting it is steadily increasing [2]. Paying attention to the potential of the discussed massifs can increase this trend and make the region attractive not only in winter. The objects shown on the geotourist map and the suggested trails are an alternative form of expanding the tourist attractions in the area under discussion. The objects marked on the map are places connected with one of a kind geological structures and interesting forms of historical heritage, landscape, and geomorphology. The marked museum (object 1, Table 1, Figure 6) makes it possible to become acquainted with this place and be familiarized with its interesting values from mineralogical and ethnological perspectives.

\section{Conclusions}

The Monchepluton and Monchetundra area is characterized by geological, geomorphological, natural, and historical heritage values. It is a place of great potential that must be cared for and made available to generations of visitors and people who live there. Protection to date only applies to the western Monchetundra massifs, not including Monchepluton. Monchepluton is an interesting example of a Paleoproterozoic layered intrusion, which also picturesquely surrounds the city of Monchegorsk and may become an interesting springboard for tourists visiting Chibiny and Murmansk in the future. In this intrusion, in addition to interesting views and geomorphological forms, it is possible to observe the rocks that formed at considerable depths of the Earth, influenced the geological history of Europe, and witnessed the disintegration of the supercontinent Kenorland 2.6 Ga years ago. Minerals of significance such as olivine and pyroxene, but also sulfides and minerals of platinum and palladium can be observed in these rocks [6,30-34]. These are ores from which chromium, nickel, copper and iron are obtained. By means of this intrusion, one can study how it was formed and how such deposits are formed. At the moment there is a museum in the town and tourist facilities in the form of hotels and restaurants. In the vicinity, there is some tourist infrastructure in the form of the above-mentioned ski lift. The authors proposed to connect the most important points of Monchepluton and Monchetundra by tourist trails, which will allow visitors to take in their values. The discussed proposal of geotourist routes allows tourists to become acquainted with the interesting heritage of the mining of nickel, copper, iron, and chromium sulfide ores and the richness of morphological and geological forms connected with the occurrence of various rocks in the area. The numerous bays of Imandra Lakes and other lakes and the Vaikis Waterfall (the highest in the Kola Peninsula region) are also attractions. The construction of tourist infrastructure in this area will be the beginning of further opportunities to enable the exploration of the western parts of the peninsula, now basically uninhabited, and to experience the whole range of natural beauty of the Arctic relatively close to the transport hub in Monchegorsk.

Author Contributions: Conceptualization, M.H. and O.I.; methodology, M.H.; software, O.I.; validation, G.Z. and M.M.; formal analysis, M.M.; investigation, M.H. and M.K.; resources, M.H.; data curation, G.Z.; writing—original draft preparation, M.H.; writing—review and editing, M.M. and G.Z.; visualization, O.I.; supervision, O.I.; project administration, M.H. All authors have read and agreed to the published version of the manuscript.

Funding: This research received no external funding.

Institutional Review Board Statement: Not applicable.

Informed Consent Statement: Not applicable.

Data Availability Statement: Not applicable.

Acknowledgments: The authors would like to express their gratitude to Jack Dunster for checking the English in our manuscript.

Conflicts of Interest: The authors declare no conflict of interest. 


\section{References}

1. Dolgiy, A.P. Kola Encyclopedia; Kiselev, A.A., Ed.; Nauka: Sankt Petersburg, Russia, 2008; p. 575. (In Russian)

2. Murmansk Visitor Center. Available online: https:/ /visitmurmansk.info/en/ (accessed on 1 July 2021).

3. Tourist Potential of Murmansk Region. Available online: www.gov-murman.ru (accessed on 1 July 2021).

4. Lapland Nature Reserve. Available online: http:/ / www.laplandzap.ru/ (accessed on 1 July 2021).

5. Aleksandrova, A.; Aigina, E. Ethno-Tourism Research in Lovozero, Murmansk Region, Russia. SHS Web Conf. 2014, 12, 1036. [CrossRef]

6. Historical Portal of Murmansk Region. Available online: http:/ / region.murman.ru/history/kola_land/ (accessed on 1 July 2021).

7. Voytekhovsky, Y.L. Geological Outdoor Map 1:50000 with a Guidebook; Kolarctic, Rovaniemi Finland Publishing House: Rovaniemi, Finland, 2014; p. 125.

8. Johansson, P.; Lauri, L.S.; Voytekhovsky, Y.L. Barents Tour for Geotourists; Kolarctic, Rovaniemi Finland Publishing House: Rovaniemi, Finland, 2014; p. 155.

9. Reynard, E.; Brilha, J. (Eds.) Geoheritage: A Multidisciplinary and Applied Research Topic. In Geoheritage: Assessment, Protection, and Management; Elsevier: Amsterdam, The Netherlands, 2018; pp. 433-438.

10. UNESCO Global Geoparks. Available online: https:/ / en.unesco.org/global-geoparks/list (accessed on 1 July 2021).

11. Alexandrowicz, Z.; Kozłowski, S. From Selected Geosites to Geodiversity Conservation-Polish Example of Modern Framework. In Towards the Balanced Management and Conservation of the Geological Heritage in the New Millennium; Berettino, D., Vallej, M., Gallego, E., Eds.; Soc. Geol. Espaa: Madrid, Spain, 1999; pp. 40-44. [CrossRef]

12. Brihla, J. Geoheritage: Inventories and evaluation. In Geoheritage: Assessment, Protection, and Management; Reynard, E., Brilha, J., Eds.; Elsevier: Amsterdam, The Netherlands, 2018; pp. 69-86.

13. Black, G.P.; Gonggrijp, G.P. Fundamental thoughts on Earth-science conservation. Jb. Geol. B 1990, 4, 655-657.

14. Elízaga, E.; Gallego, E.; García-Cortés, A. Inventaire nacional des sites d'intérêt geologique en Espagne: Méthodologie et déroulement. Mém. Soc. Geol. Fr. 1994, 165, 103-109.

15. Gray, M. Geodiversity: Developing the paradigma. Proc. Geol. Assoc. 2008, 119, 287-298. [CrossRef]

16. Gray, M. Geodiversity. Valuing and Conserving Abiotic Nature; Wiley Blackwell: Chichester, UK, 2013.

17. Zgłobicki, W.; Baran-Zgłobicka, B. Geomorphological Heritage as a Tourist Attraction. A Case Study in Lubelskie Province, SE Poland. Geoheritage 2013, 5, 137-149. [CrossRef]

18. Gray, M. Geodiversity and Geoconservation: What, Why, and How? George Wright Forum 2005, 22, 4-12.

19. Brocx, M.; Semeniuk, V. Geoheritage and geoconservation-History, definition, scope, and scale. J. R. Soc. West. Aust. 2007, 90, 53-87.

20. Henriques, M.H.; Dos Reis, R.P.; Brilha, J.B.; Mota, T. Geoconservation as an Emerging Geoscience. Geoheritage 2011, 3, 117-128. [CrossRef]

21. Burek, C.V.; Prosser, C.D. The history of geoconservation: An introduction. Geol. Soc. Lond. Spec. Publ. 2008, 300, 1-5. [CrossRef]

22. Bratton, A.; Smith, B.; McKinley, J.; Lilley, K. Expanding the Geoconservation Toolbox: Integrated Hazard Management at Dynamic Geoheritage Sites. Geoheritage 2013, 5, 173-183. [CrossRef]

23. Tomić, N.; Božić, S. A modified Geosite Assessment Model (M-GAM) and Its Application on the Lazar Canyon Area (Serbia). J. Environ. Res. 2014, 8, 1041-1052.

24. Antić, A.; Tomić, N.; Marković, S. Karst geoheritage and geotourism potential in the Pek River lower basin (eastern Serbia). Geogr. Pannon. 2019, 23, 32-46. [CrossRef]

25. Crofts, R.; Gordon, J.E.; Santucci, V.L. Geoconservation in Protected Areas. In Protected Area Governance and Management; Worboys, G.L., Lockwood, M., Kothari, A., Feary, S., Pulsford, I., Eds.; ANU Press: Gland, Switzerland, 2015; pp. 533-568.

26. Huber, M.; Zhigunova, G.V.; Bayanova, T.B.; Iakovleva, O.A. Geopark on the Kola Peninsula, perspectives of creation and development. In Proceedings of the International Conference Development of the Arctic Territory, Problems, Perspectives, Murmansk, Russia, 12-15 December 2017.

27. Huber, M.; Iakovleva, O.; Zhigunova, G.; Menshakova, M.; Gainanova, R. Can the Arctic be saved for the next generations? Study of examples and internships in Murmansk District. IOP Conf. Ser. Earth Environ. Sci. 2021, 678, 012031. [CrossRef]

28. Stone Hammer Geopark, Canada. Available online: https://www.nbm-mnb.ca/stonehammer-unesco-global-geopark/ (accessed on 1 July 2021).

29. Magma Geopark in Norway. Available online: https:/ / magmageopark.no/en/ (accessed on 1 July 2021).

30. Huangshan Geopark in China. Available online: http://www.globalgeopark.org/aboutggn/list/china/6407.htm (accessed on 1 July 2021).

31. Kocheeva, N.A.; Iurkova, N.A.; Sukhova, M.G.; Redkin, A.G.; Zhuravleva, A.V. Geospatial potential and environmental changes: Case Study of Complex Nature of the Altai Geopark. J. Water Land Dev. 2021, 49, 273-281. [CrossRef]

32. Bragina, E.; Radeloff, V.; Baumann, M.; Wendland, K.; Kuemmerle, T.; Pidgeon, A. Effectiveness of protected areas in the Western Caucasus before and after the transition to post-socialism. Biol. Conserv. 2015, 184, 456-464. [CrossRef]

33. Koizumi, T.; Chakraborty, A. Geoecotourism and environmental conservation education: Insights from Japan. GeoJournal 2015, 81, 737-750. [CrossRef]

34. Korsakova, O.P. Pleistocene marine deposits in the coastal areas of Kola Peninsula (Russia). Quat. Int. 2009, 206, 3-15. [CrossRef] 
35. Bayanova, T.B. Age of Benchmark Geological Complexes of the Kola Region and Magmatism Processes Action; Nauka: Sankt Petersburg, Russia, 2004; p. 174. (In Russian)

36. Mitrofanov, F.P.; Smolkin, V.F. Stratified Intrusions of the Monchegorsk Ore Region: Petrology, Mineralization, Isotopes, Deep Structure; Kola Scientific Center, Russian Academy of Sciences: Moscow, Russia, 2004; p. 344. (In Russian)

37. Huber, M. Evolution of the Kola-Lapland Mobile Belt on the Example of Platinum-Beraning Paleoproterooic Layered Intrusion of Monchepluton; Maria Curie-Skłodowska University: Lublin, Poland, 2020; p. 234. (In Polish)

38. Pozhilienko, V.I.; Gavrilenko, B.V.; Zhirov, C.V.; Zhabin, S.V. Geology of Mineral Areas of the Murmansk Region; Kola Scientific Center, Russian Academy of Sciences: Moscow, Russia, 2002; p. 360. (In Russian)

39. Grokhovskaya, T.L.; Ivanchenko, V.N.; Karimova, O.V.; Griboedova, I.G.; Samoshnikova, L.A. Geology, mineralogy, and genesis of PGE mineralization in the South Sopcha massif, Monchegorsk complex, Russia. Geol. Ore Depos. 2012, 54, 347-369. [CrossRef]

40. Arzamastsev, A.A.; Mitrofanov, F.P. Paleozoic plume-lithospheric processes in northeastern Fennoscandia: Evaluation of the composition of the parental mantle melts and magma generation conditions. Petrology 2009, 17, 300-313. [CrossRef]

41. Glebovitsky, V.A. Early Precambrian of the Baltic Shield; Nauka: St Petersburg, Russia, 2005; p. 710.

42. Borisenko, E.S.; Bayanova, T.B.; Nerovich, L.I.; Kunakkuzin, E. The paleoproterozoic Monchetundra mafic massif (Kola Peninsula): New geological and geochronological data. Dokl. Earth Sci. 2015, 465, 1107-1111. [CrossRef]

43. Bayanova, T.; Korchagin, A.; Mitrofanov, A.; Serov, P.; Ekimova, N.; Nitkina, E.; Kamensky, I.; Elizarov, D.; Huber, M. Long-Lived Mantle Plume and Polyphase Evolution of Palaeoproterozoic PGE Intrusions in the Fennoscandian Shield. Minerals 2019, 9, 59. [CrossRef]

44. Bozhko, N.A. Intraplate basic-ultrabasic magmatism through time in terms of supercontinental cyclicity. Mosc. Univ. Geol. Bull. 2010, 65, 161-176. [CrossRef]

45. Bozhko, N.A. Supercontinental cyclicity in the Earth's evolution. Mosc. Univ. Geol. Bull. 2009, 64, 75-91. [CrossRef]

46. Ernst, R.; Bleeker, W. Large igneous provinces (LIPs), giant dyke swarms, and mantle plumes: Significance for breakup events within Canada and adjacent regions from 2.5 Ga to the Present. Can. J. Earth Sci. 2010, 47, 695-739. [CrossRef]

47. Ernst, R.E.; Srivastava, R.K. India's Place in the Proterozoic World, Constraints from the Large Igneous Provinces (LIP) Record. In Indian Dykes: Geochemistry, Geophysics, and Geochronology; Srivastava, R.K., Sivaji, C., Chalapathi Rao, N.V., Eds.; Narosa Publishing House Pvt. Ltd.: New Delhi, India, 2008; pp. 41-56.

48. Evans, D.A.D.; Li, Z.X.; Murphy, J.B. Four-Dimensional Context of Earth's Supercontinent; The Geological Society of London, Special Publications: London, UK, 2016; Volume 424, pp. 1-14.

49. Lubnina, N.V.; Slabunov, A.I. Reconstruction of the Kenorland supercontinent in the Neoarchean based on paleomagnetic and geological data. Mosc. Univ. Geol. Bull. 2011, 66, 242-249. [CrossRef]

50. Huber, M.; Halas, S.; Piestrzyński, A. Petrology of Gabbroides and Isotope Signature of Sulfide Mineralization from FedorovPansky Layered Mafic Intrusion, Kola Peninsula, Russia. Geochronometria 2009, 33, 19-22. [CrossRef]

51. Baluev, A.S.; Zhuravlev, V.; Przhiyalgovskii, E. New data on the structure of the central part of the White Sea paleorift system. Dokl. Earth Sci. 2009, 427, 891-896. [CrossRef]

52. Britvin, S.N.; Ivanov, G.Y.; Yakuvenchuk, V.N. Mineralogical Accessory on the Kola Peninsula; World of Stones: Apatity, Russia, 1995; p. 56. (In Russian)

53. Bozhko, N.A. On two types of supercontinental cyclicity. Mosc. Univ. Geol. Bull. 2011, 66, 313-322. [CrossRef]

54. Grebnev, R.A.; Rundkvist, T.V.; Pripachkin, P.V. Geochemistry of mafic rocks of the PGE-bearing Vurechuaivench Massif (Monchegorsk Complex, Kola region). Geochem. Int. 2014, 52, 726-739. [CrossRef]

55. Huber, M.A.; Hałas, S.; Neradovsky, Y.N.; Bayanova, T.B.; Mokrushin, A.W.; Lata, L. Stable isotope geochemistry of sulfides from intrusion in Monchegorsk, northern part of Baltic Shield. Geochronometria 2016, 43, 96-101. [CrossRef]

56. Huber, M.; Hałas, S.; Serov, P.A.; Ekimova, N.A.; Bayanova, T.B. Stable isotope geochemistry, and Sm-Nd, U-Pb dating of sulfides from layered intrusions in the northern part of Baltic Shield. Cent. Eur. Geol. 2013, 56, 134-135.

57. Lubnina, N.V.; Pasenko, A.M.; Novikova, M.A.; Bubnov, A.Y. The East European craton at the end of the Paleoproterozoic: A new paleomagnetic pole of 1.79-1.75 Ga. Mosc. Univ. Geol. Bull. 2016, 71, 8-17. [CrossRef]

58. Aune, S.; Hofgaard, A.; Söderström, L. Contrasting climate- and land-use-driven tree encroachment patterns of subarctic tundra in northern Norway and the Kola Peninsula. Can. J. For. Res. 2011, 41, 437-449. [CrossRef]

59. Møller, J.J.; Yevzerov, V.Y.; Kolka, V.V.; Corner, G.D. Holocene raised-beach ridges and sea-ice-pushed boulders on the Kola Peninsula, northwest Russia: Indicators of climatic change. Holocene 2002, 12, 169-176. [CrossRef]

60. Konstantinova, N.A. Flora and Vegetation of Murmansk Region; Kola Science Centre, RAS: Apatity, Russia, 1999; p. 175. (In Russian)

61. Koroleva, N.E. Phytosociological survey of the tundra vegetation of the Kola Peninsula, Russia. J. Veg. Sci. 1994, 5, 803-812. [CrossRef]

62. Konstantinov, A.S.; Koryakin, O.A.; Makarova, V.V. Red Book of the Murmansk Region, 2nd ed.; Asia-Print: Kemerovo, Russia, 2014; p. 584. (In Russian)

63. Trutnev, Y.P.; Kamelin, R.V. Red Book of the Russian Federation (Plants and Mushrooms); Partnership of Scientific Publications KMK: Moscow, Russia, 2008; p. 855. (In Russian)

64. James-Williamson, S.A.; Aratram, M.; Green, P.E. Protecting Geoheritage in the Caribbean-Insights from Jamaica. Geoheritage 2017, 9, 195-209. [CrossRef] 
65. Williams, F. Safeguarding Geoheritage in Ethiopia: Challenges Faced and the Role of Geotourism. Geoheritage 2020, $12,31$. [CrossRef]

66. Woo, K.S.; Chun, S.S.; Moon, K.O. Outstanding Geoheritage Values of the Island-Type Tidal Flats in Korea. Geoheritage 2020, $12,8$. [CrossRef]

67. Kubalíková, L. Geomorphosite assessment for geotourism purposes. Czech J. Tour. 2013, 2, 80-104. [CrossRef]

68. Vujičić, M.D.; Vasiljević, D.J.A.; Marković, S.B.; Hose, T.A.; Lukić, T.; Hadžić, O.; Janićević, S. Preliminary geosite assessment model (GAM) and its application on Fruška Gora Mountain, potential geotourism destination of Serbia. Acta Geogr. Slov. 2011, 51, 361-377. [CrossRef]

69. Huber, M.; Iakovleva, O.; Zhigunova, G.; Menshakova, M.; Gainanova, R.; Moroniak, M. Geoheritage of the Western Khibiny Ingenious Alkaline Rocks Intrusion (Kola Peninsula, Arctic Russia): Evaluation and Geotourism opportunities. Geoheritage 2021, 13, 72. [CrossRef]

70. United Nations Educational, Scientific, and Cultural Organization. UNESCO Geoparks Programme-A new initiative to promote a global network of Geoparks safeguarding, and developing selected areas having significant geological features. In Proceedings of the Executive Board Meeting, Hundred, and Fifty-Sixth Session (156 EX/11 Rev.), Paris, France, 15 April 1999 ; p. 3.

71. United Nations Educational, Scientific, and Cultural Organization. Global Geoparks Network. Paris Division of Ecological, and Earth Sciences; UNESCO: Paris, France, 2011.

72. Leibenzon, G. On screen Monchegorsk. Kola Nickel 2010, 6, 398.

73. Lukuchev, Y.C. City in the Beautiful Tundra. Local History Narrative; Sever: Murmansk, Russia, 1993.

74. Wimbledon, W.A.P.; Smith-Meyer, S. Geoheritage in Europe and Its Conservation; ProGeo: Oslo, Norway, 2012.

75. Reynard, E. Scientific research and tourist promotion of geomorphological heritage. Geogr. Fis. Din. Quat. 2008, 31, 225-230.

76. Reynard, E. The Assessment of Geomorphosites. In Geomorphosites; Reynard, E., Coratza, P., Regolini-Bissig, G., Eds.; Verlag Dr. Friedrich Pfeil: München, Germany, 2009; pp. 63-71.

77. Reynard, E.; Regolini-Bissig, G.; Kozlik, L.; Benedetti, S. Assessment and promotion of cultural geomorphosites in the Trient Valley (Switzerland). Mem. Descr. Carta Geol. d'Ital. 2009, 87, 181-189.

78. Farsani, N.T.; Esfahani, M.A.G.; Shokrizadeh, M. Understanding Tourists' Satisfaction and Motivation Regarding Mining Geotours (Case Study: Isfahan, Iran). Geoheritage 2018, 11, 681-688. [CrossRef]

79. Gravis, I.; Németh, K.; Twemlow, C.; Németh, B. The Case for Community-Led Geoheritage and Geoconservation Ventures in Māngere, South Auckland, and Central Otago, New Zealand. Geoheritage 2020, 12, 19. [CrossRef]

80. Hose, T.A. 3G's for Modern Geotourism. Geoheritage 2012, 4, 7-24. [CrossRef]

81. Steiger, R.; Jäger, E. Subcommission on geochronology: Convention on the use of decay constants in geo- and cosmochronology. Earth Planet. Sci. Lett. 1977, 36, 359-362. [CrossRef]

82. Vdovets, M.S.; Silantiev, V.V.; Mozzherin, V.V. A National Geopark in the Republic of Tatarstan (Russia): A Feasibility Study. Geoheritage 2010, 2, 25-37. [CrossRef]

83. Zangmo, T.G.; Kagou, A.D.; Nkouathio, D.G.; Gountié, M.D.; Kamgang, P. The Volcanic Geoheritage of the Mount Bamenda Calderas (Cameroon Line): Assessment for Geotouristic and Geoeducational Purposes. Geoheritage 2017, 9, 255-278. [CrossRef]

84. Errami, E.; Brocx, M.; Semeniuk, V. From Geoheritage to Geoparks. Case Studies from Africa and beyond; Springer International Publishing: Cham, Switzerland, 2015; p. 269. [CrossRef]

85. Erikstad, L. Geoheritage and geodiversity management-The questions for tomorrow. Proc. Geol. Assoc. 2013, 124, 713-719. [CrossRef]

86. Gürer, A.; Gürer, Ö.F.; Sangu, E. Compound geotourism and mine tourism potentiality of Soma region, Turkey. Arab. J. Geosci. 2019, 12, 734. [CrossRef]

87. Cayla, N. An Overview of New Technologies Applied to the Management of Geoheritage. Geoheritage 2014, 6, 91-102. [CrossRef]

88. Prosser, C.D. Geoconservation, Quarrying and Mining: Opportunities and Challenges Illustrated through Working in Partnership with the Mineral Extraction Industry in England. Geoheritage 2018, 10, 259-270. [CrossRef]

89. Dos Santos, W.F.S.; Carvalho, I.; Brilha, J. Public Understanding on Geoconservation Strategies at the Passagem das Pedras Geosite, Paraíba (Brazil): Contribution to the Rio do Peixe Geopark Proposal. Geoheritage 2019, 11, 2065-2077. [CrossRef]

90. Burek, C. The Role of LGAPs (Local Geodiversity Action Plans) and Welsh RIGS as Local Drivers for Geoconservation within Geotourism in Wales. Geoheritage 2012, 4, 45-63. [CrossRef] 